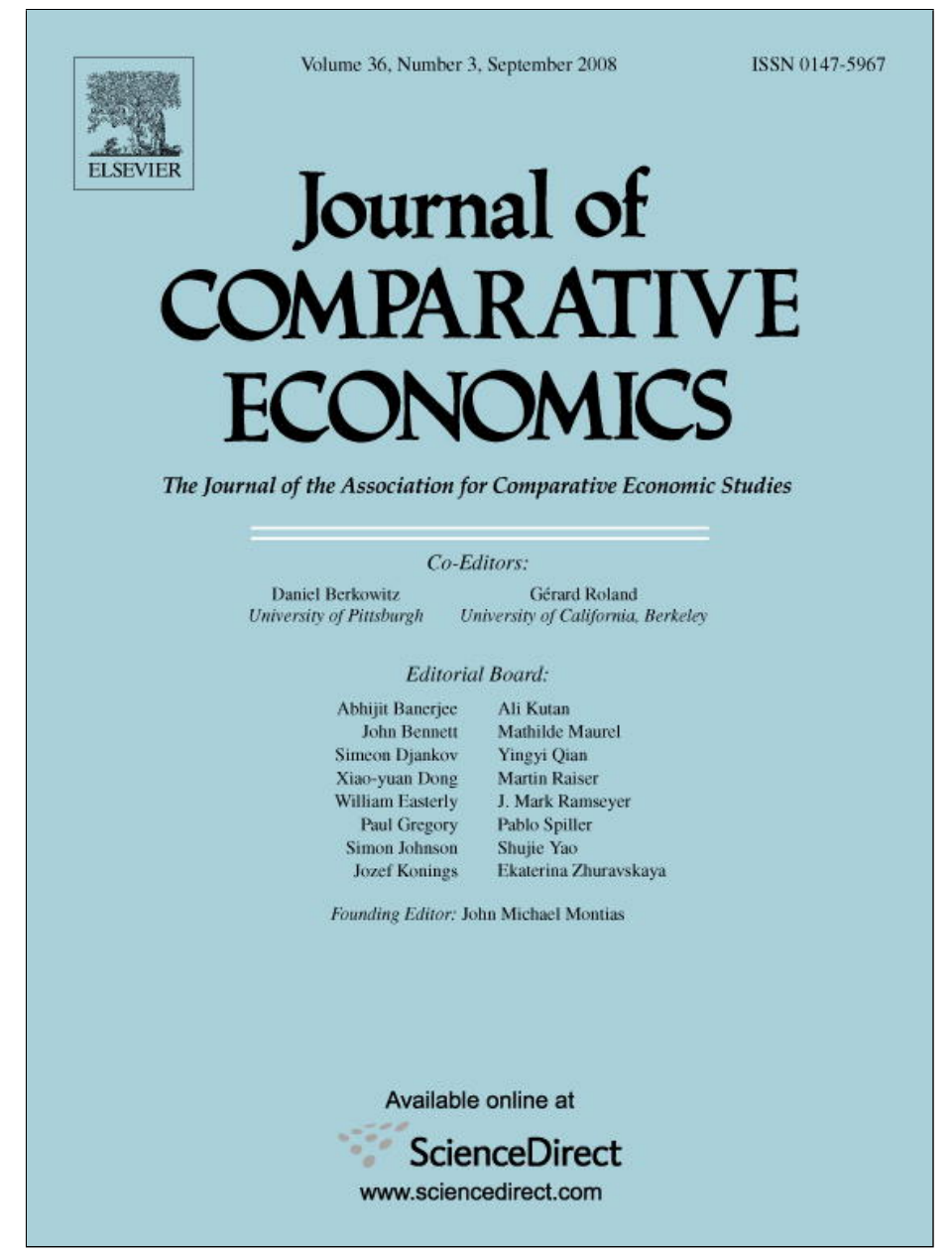

This article appeared in a journal published by Elsevier. The attached copy is furnished to the author for internal non-commercial research and education use, including for instruction at the authors institution and sharing with colleagues.

Other uses, including reproduction and distribution, or selling or licensing copies, or posting to personal, institutional or third party websites are prohibited.

In most cases authors are permitted to post their version of the article (e.g. in Word or Tex form) to their personal website or institutional repository. Authors requiring further information regarding Elsevier's archiving and manuscript policies are encouraged to visit:

http://www.elsevier.com/copyright 


\title{
Public governance and corporate finance: Evidence from corruption cases
}

\author{
Joseph P.H. Fan ${ }^{\mathrm{a}, *}$, Oliver Meng Rui ${ }^{\mathrm{a}}$, Mengxin Zhao ${ }^{\mathrm{b}}$ \\ a Faculty of Business Administration, The Chinese University of Hong Kong, Hong Kong \\ b Department of Finance, University of Alberta, Canada
}

\section{A R T I C L E I N F O}

\section{Article history:}

Received 16 January 2008

Revised 27 April 2008

Available online 17 May 2008

\section{JEL classification:}

D23

G32

G38

K42

P26

P31

\section{Keywords:}

Public governance

Corruption

Rent seeking

Regulated firms

Corporate finance

Capital structure

China

\begin{abstract}
A B S T R A C T
Fan, Joseph P.H., Rui, Oliver Meng, and Zhao, Mengxin-Public governance and corporate finance: Evidence from corruption cases

Cross-sectional research finds that corporate financing choices are not only affected by firm and industry factors, but also by country institutional factors. This study focuses on the roles of public governance in firm financing patterns. To conduct a natural experiment that avoids endogeneity, we identify 23 corruption scandals involving high-level government bureaucrats in China and a set of publicly traded companies whose senior managers bribed bureaucrats or were connected with bureaucrats through previous job affiliations. We report a significant decline in the leverage and debt maturity ratios of these firms relative to those of other unconnected firms after the arrest of the corrupt bureaucrat in question. These relations persist even if we only focus on the connected firms that were not directly involved in the corruption cases. The relative decline in firm leverage is associated with negative stock price effects. We also examine the possibility that rent seekers are efficient firms and that corruption does not thus result in capital misallocation, but fail to find evidence to substantiate this postulation. Journal of Comparative Economics 36 (3) (2008) 343-364. Faculty of Business Administration, The Chinese University of Hong Kong, Hong Kong; Department of Finance, University of Alberta, Canada.
\end{abstract}

(C) 2008 Association for Comparative Economic Studies. Published by Elsevier Inc. All rights reserved.

\section{Introduction}

It is well known that debt, and in particular short-term debt, is the dominant external financing source for companies in developing economies and emerging markets. The high corporate financial leverage in emerging markets, and more generally differences in corporate financing structures across countries, can only be partially explained by conventional theories that focus on firm or industry factors. ${ }^{1}$ Several recent cross-country studies have revealed that a significant part of the corporate financing patterns that are unexplained by firm or industry factors can be explained by country-level institutional factors (Demirguc-Kunt and Maksimovic, 1996, 1998, 1999, 2001; Rajan and Zingales, 1995; Booth et al., 2001; Giannetti, 2003; Fan et al., 2005).

Cross-sectional studies, however, are subject to potential endogeneity. To address this concern, this study adopts an event study approach and focuses on the impact of public governance on corporate financing decisions in a country. In contrast to previous cross-country studies, the single-country event study allows us to focus on a specific institutional factor while holding constant other institutional factors that may be correlated with corporate financing decisions.

\footnotetext{
* Corresponding author at: The Chinese University of Hong Kong, Faculty of Business Administration, Room 201C, Hong Kong.

E-mail addresses: pjfan@cuhk.edu.hk (J.P.H. Fan), oliver@cuhk.edu.hk (O.M. Rui), mengxin1@ualberta.ca (M. Zhao).

1 Such studies include those of Modigliani and Miller (1958), Miller (1977), Bradley et al. (1984), Myers and Majluf (1984), Titman and Wessels (1988), Barclay and Smith (1995), MacKay and Phillips (2001), and many others.
} 
In an economy plagued by poor public governance, firms are likely to raise finance through more debt, rather than equity. First, debt provides investors with a higher degree of monitoring and enforcement ability (Smith and Warner, 1979) than an open-ended equity claim, which provides little protection from expropriation by managers or bureaucrats. Second, it may be easier for self-interested bureaucrats to channel funds in the form of loans to firms with which they have connections through banks they control (La Porta et al., 2002; Sapienza, 2004), rather than through the equity market that they are less able to influence. Similar considerations apply to debt maturity. In a more corrupt system, short-term debts are more common because they provide better protection to lenders than long-term debts. However, politically connected or bribing firms are likely to have better access to long-term debt than unconnected firms.

We test the second explanation of firm financing-the rent-seeking hypothesis in emerging markets. A direct test of the hypothesis requires evidence of the misconduct of bureaucrats while avoiding the confounding factors and endogeneity problems that are typical of cross-sectional studies. To facilitate such a natural experiment, we collect a sample of 23 highlevel (mostly provincial) corruption cases involving government officers in China during the period 1995 to 2003 . Among the 393 publicly listed companies located within the jurisdiction of the corrupt bureaucrats, we identify 85 companies whose senior managers or directors bribed the bureaucrat in question (bribing firms) or were connected with the bureaucrat through past job affiliations (connected firms). We examine the leverage and debt maturity of the bribers and the connected firms and how these financing structures change relative to those of unconnected matching firms around the time of the relevant corruption case. Our empirical design is less subject to endogeneity concerns than previous studies because the corruption enforcement is exogenous to the firms and not directly caused by them. In particular, the connected firms did not necessarily actively invest in bribes, but rather gained their connections by chance, and therefore any change in their financing policy should not be directly caused by corruption but rather by lost connections.

We find that the financial leverage of both the bribers and the connected firms, as measured by total debt over total assets, was significantly less than that of the unconnected (or matching) firms subsequent to the arrest of the corrupt bureaucrats. The relative decline in leverage is more attributable to the decrease in long-term debt than to the decrease in short-term debt. Consistently, the debt maturities of the bribing firms and connected firms, as measured by long-term debt over total debt, were significantly shortened subsequent to the arrest of the bureaucrats. These results suggest that being connected with corrupt bureaucrats provides firms with a comparative advantage in obtaining access to debt, and in particular long-term debt. However, this debt financing advantage disappears when the connection is broken due to the arrest of the bureaucrat in question. Our results are robust to various leverage and maturity measures, the inclusion of supplier credits as an additional source of financing, the inclusion of various control variables, and several alternative interpretations.

We also perform an event study to examine whether any of the lost financing advantage is reflected in a lower firm value by estimating the cumulative abnormal stock returns (CARs) of the firms around the initial public release of the corruption news. We find that the CARs are positively related to change in leverage around the corruption events for various event windows, which suggests that stock markets discount the value of firms that experience a decrease in financial leverage (or an increase that is not as great as that of other firms) due to the corruption allegations.

Finally, we address the question of whether rent-seeking activities and capital allocation efficiency in China's financial system can coexist, given that more efficient firms are more likely to pay bribes or build connections to secure their access to capital. However, we are unable to find any evidence for this postulation.

Our findings suggest that public sector governance has an important effect on corporate financing behavior. This is broadly consistent with the economic literature, which shows that political rent-seeking explains firm behavior and value, financial sector development, and economic growth (Shleifer and Vishny, 1994, 1998; Fisman, 2001; Johnson et al., 2002; Johnson and Mitton, 2003; Ramalho, 2003; Acemoglu and Johnson, 2005; Faccio, 2006; Charumilind et al., 2006; Leuz and Oberholzer-Gee, 2006). Our evidence also corroborates the findings of several other papers. Khawaja and Mian (2005) report that politically connected firms in Pakistan receive abnormal lending from government banks and suffer from abnormal default rates. In a cross-country study, Dinc (2005) reports that government-owned banks tend to increase their lending in election years relative to private banks. Siegel (2005) reports that Korean firms that are connected to politicians gain better access to key outside resources through cross-border alliances. In another cross-country study, Faccio et al. (2006) report that politically connected firms are more likely to be bailed out by governments, and that their performance is worse subsequent to such bailouts than that of non-connected firms. Claessens et al. (in press) document that Brazilian firms that make large contributions to federal deputy election campaigns are more likely to have an increased bank leverage after such elections.

The remainder of this paper proceeds as follows. Section 2 provides an overview of the financial markets and rentseeking activities in China. Section 3 presents the sample, data, and the empirical results of the effects of corruption events on capital and debt maturity structures. Section 4 analyzes the impact of financial policy changes on performance. Section 5 addresses the effects of corruption on capital allocation. Section 6 concludes the paper.

\section{Institutional background}

This section describes rent-seeking and corruption activities in China, the Chinese financial market, and how rent-seeking activities shape the financing decisions of firms. 


\subsection{Corruption in China}

China is rapidly becoming one of the largest economies in the world and a leading destination for investment. However, it is also regarded as a highly corrupt country. According to the official records of the Central Commission for Discipline Inspection of the Communist Party of China for the period 1997-2002, 861,917 corruption cases were under investigation, 842,760 corruption cases had been concluded, and some 846,150 people were punished by Communist Party law, of whom 137,711 were expelled from the party. The Heritage Foundation and Wall Street Journal co-publish the Index of Economic Freedom, which ranks countries on 50 independent economic variables including those related to corruption in the judiciary, the rule of law, and contract enforcement. The United States ranks 6th overall, whereas China ranks 128 th out of the 161 countries featured in the index. ${ }^{2}$ La Porta et al. (2004) report that China is among the worst countries in terms of political freedom and the protection of property rights. China ranks 71 out of 145 countries on the Corruption Perception Index of Transparency International. ${ }^{3}$

\subsection{Corporate financing activities in China}

China maintains a government-dominated financial system, in which the government tightly controls entry to commercial banking, investment banking, and other financial services. The banking system in China comprises the central bank, four large state-owned commercial banks, ${ }^{4}$ three policy banks, ${ }^{5} 10$ national joint-stock commercial banks, about 90 regional commercial banks, and about 3000 urban and 42,000 rural credit cooperatives. There are also branches or representative offices of foreign banks that engage in limited activities. Overall, the four state-owned commercial banks dominate the lending market.

Although China's two major stock exchanges-Shanghai and Shenzhen-have only existed since 1990 and 1991, respectively, the number of companies listed on them had grown to 1377 by the end of 2004 . The total market capitalization of these listed firms at that time was US\$448.6 billion, which is equal to about $36 \%$ of China's gross domestic product. ${ }^{6}$ However, despite this phenomenal growth, equity financing still lagged far behind debt financing in terms of the preferred mode of financing in the period 1993 to $2001 .^{7}$

Allen et al. (2005a, 2005b) report that debt financing is the dominant mode of corporate finance, and that most bank credits are issued to companies in the State and Listed Sectors. ${ }^{8}$ They also show that China's banking system runs at a low efficiency, as revealed by the large amount of non-performing loans (NPL) owned by the four state-owned commercial banks. ${ }^{9}$ A large proportion of these NPLs are the result of poor lending decisions made about state-owned enterprises, some of which are due to political or other non-economic reasons.

The bond market in China is still underdeveloped. By our estimation using data from the China Statistical Yearbook, the outstanding amount of total corporate bonds was about $4 \%$ of total bank loans in 2005, and even lower in earlier years. According to an estimation by the Federal Reserve Bank of San Francisco (2007), the corporate bond market provided only $1.4 \%$ of the total capital raised by corporations in China in 2006 , whereas the commercial banks provided $85 \%$. ${ }^{10}$

China's politicians and bureaucrats have a strong influence over the allocation of bank loans, because the state controls most of the financial resources through its ownership of the banks. Nevertheless, corruption is pervasive in the financial sector in China. ${ }^{11}$ Obtaining large-scale data on either detected or undetected criminal cases is difficult due to China's

\footnotetext{
2 More details are available at www.heritage.org/research/features/index/search.cfm.

3 The index measures the "degree to which corruption is perceived to exist among public officials and politicians. It is a composite index, drawing on 14 different polls and surveys from seven independent institutions, carried out among business people and country analysis, including surveys of residents, both local and expatriate." Source: Transparency International.

4 The four state-owned banks are the Industrial and Commercial Bank of China (ICBC), the Agriculture Bank of China (ABC), the Bank of China (BOC), and the China Construction Bank (CCB). As of late 2001, they accounted for 63 percent of loans outstanding and 62 percent of deposits. With 103,000 branches among them, they are the only financial institutions that cover virtually every location in China. All of the banks in China are controlled by either the state or the local government.

5 The three policy banks were established during the reform of the financial system in 1994 to take over responsibility for policy loans from the four state commercial banks. Their mandate includes making policy or low-interest loans to large government infrastructure investment projects specified by government polices, providing agricultural financial services and subsidiary financing for the acquisition and storage of agricultural products, and supporting import and export credit for electronic and machinery equipment systems.

6 This information was obtained from the China Securities Regulatory Commission (CSRC) website at www.csrc.gov.cn.

7 Tong (2005) estimates that equity financing only represented $10 \%$ to $20 \%$ of all financing among listed firms in this period.

$8 \mathrm{Li}$ et al. (2007) also find that state-owned enterprises have better access to bank loans.

9 Statistics show that the outstanding NPLs of major Chinese banks amounted to 2.44 trillion yuan (289.96 billion US dollars) by the end of 2003, with an NPL ratio of 17.8 percent. The big four state-owned commercial banks accounted for 1.91 trillion yuan (230.76 billion US dollars), with an NPL of 20.36 percent.

10 Prospects for China's Corporate Bond Market, Federal Reserve Bank of San Francisco Economic Letter, Number 2007-07, March 16, 2007.

11 Chinese anti-corruption officials have turned their attention to the financial industry recently, as corruption in the financial system is now viewed as being more destructive to the country's financial health than any other problem. Wang Xuebing, former governor of the Construction Bank of China, was sentenced to 12 years' imprisonment in 2002 on a charge of accepting bribes worth 1.15 million yuan (US\$139,000) in the period 1993 to 2001. Liu Jinbao, vice-president of the Bank of China, received a suspended death sentence for in 2005 for embezzling 14.48 million yuan (US\$1.75 million), of which he personally pocketed 7.72 million yuan. He also received bribes amounting to 1.43 million yuan and was unable to account for 14.78 million yuan in personal assets.
} 
opaque information disclosure policy. However, a review of the overall financial system and stylized observations suggest that a link between corporate finance and rent seeking is plausible. We examine this link in the next section.

\section{Empirical analysis}

This section describes the sample, provides basic statistics on the financing structures of the sample firms, and reports the regression results for the effects of rent seeking on the financing structures of the firms around the time of corruption events.

\subsection{Sample and data}

\subsubsection{The sample}

To examine how corporate financing policies change with rent-seeking activities, we compile a list of corruption cases that involved high-level government officers in China and identify listed firms that were connected to these corrupt bureaucrats. We focus on high-profile cases rather than general corruption scandals, because they have a larger impact on the corporate sector and the information disclosure about these cases is better. Moreover, focusing on these high-level cases mitigates the potential endogeneity problem that corporate financing may cause corruption enforcement. As the bringing of high-level corruption cases in China is typically political and non-systematic, the arrest of bureaucrats is unlikely to be due to their providing financing to rent-seeking firms per se.

We employ the following procedures to collect the corruption cases. We first identify a list of corrupt bureaucrats from three government publications that disclose high-profile corruption cases, mostly about bureaucrats at the central and provincial government levels. We collect 11 cases from The Law Yearbook of China (1999-2005) published by the Law Yearbook of China Publisher, three cases from Excerpts of Disciplinary Cases of the Communist Party of China published by the Central Commission for Discipline Inspection of the Communist Party of China, and 20 cases from Villains of the Communist Party of China published by the Law Publisher in 2004 . $^{12}$ We also make efforts to collect additional cases publicized by the Central Commission for Discipline Inspection of the Communist Party of China and various Chinese courts through China's official news agency, Xinhua News. After excluding overlapping cases, we identify 23 high-level government officer corruption cases that occurred during the period 1995 to 2003.

Among the 23 cases, 20 involve provincial level government bureaucrats, one involves central government bureaucrats, and two involve the top executives of major state-owned national banks. For each of the provincial corruption cases, we examine all of the publicly traded companies located in the corrupt bureaucrat's jurisdiction around the time of the corruption event. For each of the companies, we search through the aforementioned three government publications and all of the available news disclosures about the investigation and ensuing lawsuits to find out whether any of the company's senior managers, directors, or top 10 shareholders bribed the bureaucrat in question. For the three remaining cases that involve the central government and banks, we do not restrict our search to related firms in a province, but instead identify all publicly listed firms across China that bribed the relevant central government or bank officers. Of the 393 companies that fit our investigation criteria, 43 companies are identified as bribing firms.

To facilitate a natural experiment to determine the effects of rent seeking on firm financing policies we next identify a set of firms that were connected with the corrupt bureaucrats but were not bribers nor otherwise involved in the corruption cases. Again, for each company located in the jurisdiction of the relevant corrupt bureaucrat, we search through the company's initial public offering prospectus and annual reports before the corruption event to find out whether any senior managers, directors, or large shareholders were family members of or had previous job affiliations with the corrupt bureaucrat in question. We are able to identify 42 companies with such connections, almost all of which are job connections. We call these firms connected firms.

We admit that we may have missed some bribers or connected firms due to information limitations. However, we did not find in our data collection that the extent of the disclosure of individual or firm involvement greatly differs among the cases, and therefore any mis-classifications are likely to be random and would only bias significant findings. We may also have missed some event firms because we limit our search to the jurisdiction of the corrupt bureaucrats. Such omissions would naturally weaken our results.

The remaining 308 listed companies in the jurisdictions of the corrupt bureaucrats were neither bribers nor connected with the corrupt bureaucrats, and thus we call them unconnected firms. These firms may well be connected with other bureaucrats, but as long as those bureaucrats were not involved in corruption scandals, the financing choices of the firms will not be affected.

Appendix A provides an example of our sample identification process, and Table 1 summarizes the 23 corruption cases and associated sample firms. The corruption cases were all initially disclosed (event day) between 1995 and 2003 , but the sentencing day is usually a few months to a few years after the event day. The punishment received by the arrested bureaucrats varies from the death penalty to dismissal from their position or the Communist Party. Appendix B provides a summary of each of the corruption scandals and the sources from which this information was gleaned.

\footnotetext{
12 The book titles are translated from Chinese.
} 
Table 1

\begin{tabular}{|c|c|c|c|c|c|c|c|c|c|}
\hline Province & Name & Position & Event day & Sentence day & Sentence & $\begin{array}{l}\text { Number of firms } \\
\text { in the province }\end{array}$ & $\begin{array}{l}\text { Bribing } \\
\text { firms }\end{array}$ & $\begin{array}{l}\text { Connected } \\
\text { firms }\end{array}$ & $\begin{array}{l}\text { Non-event } \\
\text { firms }\end{array}$ \\
\hline Anhui & Wang Huizhong & Provincial Vice-Governor & 20010407 & 20031229 & Death penalty & 27 & 1 & 2 & 24 \\
\hline Bank & Liu Jinbao & $\begin{array}{l}\text { Vice-Chairman and CEO of the } \\
\text { Bank Of China (HK) }\end{array}$ & 20030525 & 20050812 & Suspended death penalty & 5 & 5 & 0 & 0 \\
\hline Bank & Wang Xuebin & $\begin{array}{l}\text { CEO of the China Construction } \\
\text { Bank }\end{array}$ & 20020111 & 20031210 & 12 years' imprisonment & 5 & 5 & 0 & 0 \\
\hline Beijing & Chen Xitong & CPC Secretary & 19950426 & 19980731 & 16 years' imprisonment & 11 & 5 & 3 & 3 \\
\hline Central & Xu Penghang & $\begin{array}{l}\text { Vice-Chairman of the National } \\
\text { Defense Technology Commission } \\
\text { and National Economics and } \\
\text { Trade Commission }\end{array}$ & 20001011 & 20001011 & Dismissal from service & 1 & 1 & 0 & 0 \\
\hline Fujian & Shi Zhaobin & Vice-CPC Secretary & 19990818 & 20010927 & Dismissal from service and the CPC & 34 & 5 & 3 & 26 \\
\hline Guangxi & Xu Binsong & Municipal Vice-Chairman & 19980523 & 19990827 & Life imprisonment & 6 & 0 & 1 & 5 \\
\hline Guangxi & Chen Kejie & Municipal Chairman & 20000111 & 20000731 & Death penalty & 10 & 2 & 1 & 7 \\
\hline Guangxi & Liu Zhibin & Municipal Vice-Chairman & 20000319 & 20020624 & 15 years' imprisonment & 10 & 2 & 2 & 6 \\
\hline Guangxi & Wang Qinglu & Vice-Chairman of the PPCC & 20010222 & 20010222 & Dismissal from service and the CPC & 13 & 0 & 1 & 12 \\
\hline Guizhou & Liu Changgui & Provincial Vice-Governor & 20030417 & 20040430 & 11 years' imprisonment & 12 & 1 & 3 & 8 \\
\hline Guizhou & Liu Fangren & CPC Secretary and PC Chairman & 20030422 & 20040629 & Life imprisonment & 12 & 1 & 1 & 10 \\
\hline Hainan & Xin Yejiang & Vice-PC Chairman & 19961227 & 19980526 & 5 years' imprisonment & 10 & 2 & 0 & 8 \\
\hline Hebei & Jiang Dianwu & Vice-PC Chairman & 19971101 & 19981207 & 10 years' imprisonment & 13 & 0 & 0 & 13 \\
\hline Hebei & Chen Weigao & CPC Secretary and PC Chairman & 20000301 & 20030809 & Dismissal from the CPC & 25 & 1 & 3 & 21 \\
\hline Hubei & Meng QingPing & Provincial Vice-Governor & 19980410 & 19991201 & 10 years' imprisonment & 33 & 1 & 4 & 28 \\
\hline Jiangxi & Hu Changqing & Provincial Vice-Governor & 19990808 & 20000215 & Death penalty & 12 & 0 & 2 & 10 \\
\hline Liaoning & Mu TuoXing & Provincial Vice-Governor & 20010321 & 20011113 & Death penalty & 51 & 5 & 6 & 40 \\
\hline Xingjiang & Aman.Haji & Provincial Vice-Governor & 20031015 & $\mathrm{~N} / \mathrm{A}$ & N/A (still under investigation) & 25 & 1 & 1 & 23 \\
\hline Yunnan & Li Jiating & $\begin{array}{l}\text { Vice CPC Secretary and } \\
\text { Provincial Governor }\end{array}$ & 20010620 & 20030509 & Death penalty & 17 & 1 & 4 & 12 \\
\hline Zhejiang & Xu Yunhong & Provincial Vice-Governor & 19990922 & 20001017 & 10 years' imprisonment & 35 & 2 & 3 & 30 \\
\hline Total & & & & & & 393 & 43 & 42 & 308 \\
\hline
\end{tabular}

This table reports 23 corruption cases involving high-level bureaucrats in China. Some of the names are collected from Excerpts of Discipline Cases of the Communist Party of China and Villains of the Communist Party of China, others are collected from news disclosures by the Central Commission for Discipline Inspection of the CPC. The event day is the first day of the public disclosure of a bureaucrat's wrongdoing. Such of China, others are collected from news disclosures by the Central Commission for Discipline Inspection of the CPC. The event day is the first day of the public disclosure of a bureaucrat's wrongdoing. Such
disclosures can be Shuang Gui (a detention measure that orders the person to confess his or her crime at a specific location), arrest, or removal from their current position. The sentence day is the day when the final adjudication is announced. CPC denotes Communist Party of China. PC denotes People's Congress. PPCC denotes People's Political Consultative Congress. Bribing firms are those with senior managers or the final adjudication is announced. CPC denotes Communist Party of China. PC denotes People's Congress. PPCC denotes People's Political Consultative Congress. Bribing firms are those with senior managers or
directors that directly bribed the corrupt bureaucrats. Connected firms are those with senior managers or directors who were connected with the bureaucrats through current or past job affiliations, but were not directors that directly bribed the corrupt bureaucrats. Connected firms are those with senior managers or directors
involved in the corruption cases. Unconnected firms are all other firms in the jurisdiction of the corrupt bureaucrat. 
As Table 1 shows, the 393 firms in our sample (comprising 43 bribing firms, 42 connected firms, and the remaining 308 non-connected firms) are not concentrated in just a few provinces, but are spread across the various regions of China.

For each of the 393 firms, we collect financial data up to 2004 from the China Stock Market and Accounting Research (CSMAR) financial statement database. Daily stock prices are obtained from the CSMAR transaction database. There is no pre-event financial data for 20 of the 393 firms, of which seven are bribing firms, two are connected firms, and 11 are unconnected firms. This brings the usable number of firms for analysis down to 373.

\subsubsection{Sub-sample groupings}

For ease of discussion, we call the bribing firms and connected firms "event firms" and the unconnected firms "non-event firms." We also compare the financing patterns of the connected firms with those of the unconnected firms.

As an alternative benchmark for comparison, we identify a matching firm for each of the bribing and connected firms. Ideally, we want to select a firm that is identical to an event firm except for the fact that it was not involved in corruption nor connected with a corrupt bureaucrat. However, it is unlikely that we would be able to find an exact match. Any less stringent criteria may be subject to selection bias, and thus to mitigate this concern we use several different sets of selection criteria and examine whether our results are sensitive to the choice of selection criteria. In the first matching effort, we select a firm that is closest to the matched sample firm in terms of growth (market-to-book equity ratio), financial leverage (total debt over total assets), and industry affiliation, but that is not one of the 373 sample firms. For any corruption case involving a provincial bureaucrat, we require that any matching firm is located outside of the corrupt bureaucrat's jurisdiction. For each of the remaining 11 firms that are involved in the three central government and bank corruption cases, we identify a matching firm using the same criteria, but from the pool of all public listed firms in China (excluding the 373 sample firms). This matching process utilizes data from the third year before the event year. We are careful to select the matching firms so that they do not have connections with any of the bureaucrats captured in the 23 corruption cases. Appendix $C$ provides an example of how we select the matching firm for an event firm.

We use various other combinations of the size, growth, and industry criteria to select matching firms, and also use multiple matching firms for a given sample firm. We even use the entire population of publicly traded firms in China as a comparison benchmark. Finally, as we find that none of these comparison benchmarks affects our results and conclusions, we therefore focus on the set of results derived using the first stated criteria.

\subsection{Descriptive statistics}

A few alternative measures of corporate financing structures are employed in this study. Financial leverage is measured as total debt divided by total assets, or total debt plus accounts payable divided by total assets, all in book value. Debt maturity is measured as long-term debt divided by total debt, or long-term debt divided by total debt plus accounts payable. Longterm debt is defined as any outstanding debt that is not due within the next year. We further define long-term leverage as long-term debt divided by total assets, and short-term leverage as short-term debt divided by total assets, accounts payable divided by total assets, and short-term debt plus accounts payable divided by total assets. The inclusion of accounts payable in the alternative leverage and debt maturity measures is to account for supplier credit as a possible source of financing. ${ }^{13}$

Before examining the financing variables of the sample firms, it would be useful to generally discuss the financial structure of firms in China. The leverage ratios of Chinese firms are quite high, ranking 13 out of the 39 economies examined by Fan et al. (2005). Moreover, the debt maturities of Chinese firms are among the shortest in the world, as reported in the same study. Table 2 of this paper provides the industry-by-industry mean leverage and debt maturity ratios of all of the publicly traded firms in China during the sample period (1995-2005), and shows that the leverage ratios of Chinese firms do not vary greatly across industries. The ratio of total debt to total assets is in the range of $13 \%$ to $43 \%$ for all industries, with the paper-making industry bearing the highest leverage. In contrast, the debt maturity ratios vary substantially across the industries. Long-term debt is more prevalent in heavily regulated industries such as the chemical, petroleum, utilities, transportation, and medical industries, whereas debt maturities are much shorter for firms in consumer-based industries such as drugs and information technology. Overall, the difference in debt maturity between China's regulated (natural resources, public utilities, and metals) and less regulated sectors is large at $23 \%$. The longer maturity of debt in regulated firms is not unique to China. Barclay and Smith (1995) report for US firms during the period 1974 to 1992 that the average difference in debt maturity ratio between regulated and unregulated firms was 6.6 percentage points, where regulated industries are defined as telephone, electric, and gas utilities and airlines. We estimate the comparable figure for US publicly traded firms for the period 1995 to 2005 using the COMPUSTAT Database and find that the difference in debt maturity between regulated and less regulated firms is $12 \%$.

These cross-country and cross-industry patterns indicate that the financial structure of Chinese firms may be related to heavy regulations both at the national and at the industry levels. Previous studies (e.g., Bradley et al., 1984) also find that firms in regulated sectors tend to be more highly leveraged than less regulated firms, and thus this study extends

13 Demirguc-Kunt and Maksimovic (2001) find that trade credit is an important source of financing in economies with underdeveloped financial intermediaries, and Cull and Xu (2005) suggest that trade credit is an indirect financing channel in China. For example, firms may receive trade credits from suppliers that are cash rich or have better access to external funds. 
Table 2

Capital structure and debt maturity by industry

\begin{tabular}{|c|c|c|c|c|c|c|c|c|}
\hline Industry name & $\begin{array}{l}\text { Total debt/ } \\
\text { Total assets }\end{array}$ & $\begin{array}{l}\text { (Total debt }+ \\
\text { Account payable)/ } \\
\text { Total assets }\end{array}$ & $\begin{array}{l}\text { Long-term debt/ } \\
\text { Total debt }\end{array}$ & $\begin{array}{l}\text { Long-term } \\
\text { debt/(Total debt } \\
+ \text { Account payable) }\end{array}$ & $\begin{array}{l}\text { Long-term debt/ } \\
\text { Total assets }\end{array}$ & $\begin{array}{l}\text { Short-term debt/ } \\
\text { Total assets }\end{array}$ & $\begin{array}{l}\text { Accounts payable/ } \\
\text { Total assets }\end{array}$ & $\begin{array}{l}\text { Short-term debt } \\
\text { + Account payable)/ } \\
\text { Total assets }\end{array}$ \\
\hline Total & 0.264 & 0.336 & 0.228 & 0.164 & 0.057 & 0.207 & 0.071 & 0.278 \\
\hline Agriculture & 0.309 & 0.351 & 0.174 & 0.145 & 0.047 & 0.262 & 0.042 & 0.304 \\
\hline Mining & 0.139 & 0.208 & 0.39 & 0.218 & 0.059 & 0.079 & 0.069 & 0.149 \\
\hline Food, beverage & 0.224 & 0.285 & 0.135 & 0.083 & 0.028 & 0.196 & 0.061 & 0.257 \\
\hline Textile/apparel & 0.235 & 0.296 & 0.139 & 0.097 & 0.036 & 0.199 & 0.062 & 0.260 \\
\hline Timber, furniture & 0.277 & 0.349 & 0.122 & 0.051 & 0.015 & 0.262 & 0.072 & 0.334 \\
\hline $\begin{array}{l}\text { Paper making, } \\
\text { printing }\end{array}$ & 0.429 & 0.510 & 0.299 & 0.251 & 0.121 & 0.308 & 0.081 & 0.389 \\
\hline $\begin{array}{l}\text { Petroleum, } \\
\text { chemistry, plastics }\end{array}$ & 0.272 & 0.339 & 0.279 & 0.213 & 0.079 & 0.193 & 0.067 & 0.260 \\
\hline Electronics & 0.193 & 0.296 & 0.198 & 0.119 & 0.038 & 0.155 & 0.103 & 0.258 \\
\hline Metal, non-metal & 0.298 & 0.366 & 0.314 & 0.238 & 0.087 & 0.210 & 0.068 & 0.279 \\
\hline $\begin{array}{l}\text { Machinery, } \\
\text { equipment, } \\
\text { instrument }\end{array}$ & 0.204 & 0.330 & 0.156 & 0.086 & 0.029 & 0.176 & 0.126 & 0.301 \\
\hline $\begin{array}{l}\text { Medicine, } \\
\text { biological product }\end{array}$ & 0.237 & 0.316 & 0.153 & 0.103 & 0.032 & 0.205 & 0.079 & 0.284 \\
\hline $\begin{array}{l}\text { Other } \\
\text { manufacturing } \\
\text { industries }\end{array}$ & 0.277 & 0.324 & 0.145 & 0.116 & 0.034 & 0.244 & 0.047 & 0.291 \\
\hline $\begin{array}{l}\text { Power, gas, and } \\
\text { water }\end{array}$ & 0.269 & 0.305 & 0.522 & 0.429 & 0.153 & 0.116 & 0.036 & 0.152 \\
\hline Architecture & 0.216 & 0.368 & 0.288 & 0.176 & 0.069 & 0.147 & 0.151 & 0.298 \\
\hline Transportation & 0.202 & 0.227 & 0.405 & 0.303 & 0.087 & 0.115 & 0.025 & 0.140 \\
\hline IT & 0.249 & 0.355 & 0.121 & 0.065 & 0.023 & 0.226 & 0.106 & 0.332 \\
\hline Retail & 0.255 & 0.374 & 0.13 & 0.073 & 0.028 & 0.227 & 0.119 & 0.346 \\
\hline Real estate & 0.278 & 0.331 & 0.273 & 0.216 & 0.072 & 0.206 & 0.053 & 0.259 \\
\hline Social service & 0.201 & 0.232 & 0.297 & 0.237 & 0.059 & 0.141 & 0.031 & 0.173 \\
\hline Communication & 0.397 & 0.429 & 0.089 & 0.077 & 0.040 & 0.357 & 0.031 & 0.388 \\
\hline Conglomerate & 0.388 & 0.455 & 0.167 & 0.138 & 0.061 & 0.327 & 0.066 & 0.393 \\
\hline
\end{tabular}

0.167

0.040

0.393

assets, or total debt plus accounts payable divided by total assets. Debt maturity is measured as long-term debt divided by total debt, or long-term debt divided by total debt plus accounts payable. We furthe define long-term leverage as long-term debt divided by total assets, and short-term leverage as short-term debt divided by total assets, accounts payable divided by total assets, or short-term debt plus accounts payable divided by total assets. 
Table 3

Capital structure, debt maturity, and other firm characteristics around the corruption events

Panel A. Mean Value

\begin{tabular}{|c|c|c|c|c|c|c|c|c|}
\hline & \multicolumn{2}{|c|}{ Event firms } & \multicolumn{2}{|c|}{ Connected firms only } & \multicolumn{2}{|c|}{ Non-event firms } & \multicolumn{2}{|c|}{ Full sample } \\
\hline & Pre-event & Change & Pre-event & Change & Pre-event & Change & Pre-event & Change \\
\hline Assets & 1352.56 & 242.77 & 1140.21 & $267.97^{* *}$ & $1,335.08$ & $648.53^{* * *}$ & 1338.97 & $567.96^{* * *}$ \\
\hline Sales & 680.62 & 179.05 & 471.05 & $247.07^{* * *}$ & 747.46 & $515.49^{* * *}$ & 732.54 & $451.70^{* * *}$ \\
\hline Total debt/Assets & 0.169 & $0.106^{* * *}$ & 0.149 & $0.147^{* * *}$ & 0.145 & $0.214^{* * *}$ & 0.150 & $0.191^{* * *}$ \\
\hline (Total debt + Accounts payable)/Assets & 0.224 & $0.135^{* * *}$ & 0.207 & $0.187^{* * *}$ & 0.194 & $0.263^{* * *}$ & 0.201 & $0.236^{* * *}$ \\
\hline Long-term debt/Total debt & 0.277 & $-0.077^{* * *}$ & 0.310 & $-0.098^{* * *}$ & 0.273 & $-0.029^{* *}$ & 0.274 & $-0.039^{* * *}$ \\
\hline Long-term debt/(Total debt + Accounts payable) & 0.203 & $-0.056^{* * *}$ & 0.222 & $-0.079^{* * *}$ & 0.209 & $-0.021^{*}$ & 0.208 & $-0.027^{* * *}$ \\
\hline Long-term debt/Assets & 0.043 & -0.000 & 0.048 & -0.008 & 0.043 & $0.042^{* * *}$ & 0.043 & $0.033^{* * *}$ \\
\hline Short-term debt/Assets & 0.125 & $0.096^{* * *}$ & 0.099 & $0.142^{* * *}$ & 0.100 & $0.160^{* * *}$ & 0.105 & $0.146^{* * *}$ \\
\hline Accounts payable/Assets & 0.063 & $0.038^{* * *}$ & 0.068 & 0.040 & 0.055 & $0.055^{* * *}$ & 0.057 & $0.043^{* * *}$ \\
\hline (Short-term debt + Accounts payable)/Assets & 0.231 & $0.149^{* * *}$ & 0.198 & $0.192^{* * *}$ & 0.190 & $0.190^{* * *}$ & 0.199 & $0.181^{* * *}$ \\
\hline \multicolumn{9}{|l|}{ Panel B. Median Value } \\
\hline & \multicolumn{2}{|c|}{ Event firms } & \multicolumn{2}{|c|}{ Connected firms only } & \multicolumn{2}{|c|}{ Non-event firms } & \multicolumn{2}{|c|}{ Full sample } \\
\hline & Pre-event & Change & Pre-event & Change & Pre-event & Change & Pre-event & Change \\
\hline Assets & 925.49 & $93.74^{* *}$ & 908.96 & $313.46^{* * *}$ & 844.72 & $413.14^{* * *}$ & 856.69 & $356.24^{* * *}$ \\
\hline Sales & 338.05 & 82.24 & 307.70 & $161.09^{* * *}$ & 397.36 & $197.99^{* * *}$ & 385.20 & $169.68^{* * *}$ \\
\hline Total debt/Assets & 0.130 & $0.102^{* * *}$ & 0.086 & $0.158^{* * *}$ & 0.118 & $0.197^{* * *}$ & 0.169 & $0.176^{* * *}$ \\
\hline (Total debt + Accounts payable)/Assets & 0.167 & $0.154^{* * *}$ & 0.145 & $0.200^{* * *}$ & 0.178 & $0.233^{* * *}$ & 0.176 & $0.216^{* * *}$ \\
\hline Long-term debt/Total debt & 0.219 & $-0.133^{* * *}$ & 0.301 & $-0.217^{* * *}$ & 0.164 & -0.012 & 0.178 & $-0.039^{* * *}$ \\
\hline Long-term debt/(Total debt + Accounts payable) & 0.131 & $-0.071^{* * *}$ & 0.162 & $-0.103^{* * *}$ & 0.096 & 0.009 & 0.105 & $-0.012^{* *}$ \\
\hline Long-term debt/Assets & 0.009 & -0.003 & 0.020 & -0.006 & 0.003 & $0.038^{* * *}$ & 0.004 & $0.022^{* * *}$ \\
\hline Short-term debt/Assets & 0.089 & $0.098^{* * *}$ & 0.057 & $0.136^{* * *}$ & 0.072 & $0.148^{* * *}$ & 0.074 & $0.136^{* * *}$ \\
\hline Accounts payable/Assets & 0.048 & $0.032^{* * *}$ & 0.055 & $0.034^{* * *}$ & 0.044 & $0.019^{* * *}$ & 0.045 & $0.031^{* * *}$ \\
\hline (Short-term debt + Accounts payable)/Assets & 0.198 & $0.110^{* * *}$ & 0.159 & $0.166^{* *}$ & 0.171 & $0.156^{* * *}$ & 0.176 & $0.147^{* * *}$ \\
\hline
\end{tabular}

This table reports the pre-event three-year mean (Panel A) and median (Panel B) values of leverage, debt maturity, firm asset, and sales for the sample firms and several sub-samples-the event firms, the connected firms, and the non-event firms. "Change" is measured as the three-year mean (median) value of a variable after the event minus the three-year mean (median) before the event. The event firms include the bribing firms and the connected firms. Bribing firms are those with senior managers or directors who directly bribed the bureaucrats involved in the corruption case. Connected firms are those with senior managers or directors connected with the corrupt bureaucrats through current or past job affiliations, but who were not involved in the corruption case. Non-event firms are other non-bribing, non-connected firms within the jurisdiction (province) of the corrupt bureaucrat. Financial leverage is measured as total debt divided by total assets, or total debt plus accounts payable divided by total assets. Debt maturity is measured as long-term debt divided by total debt, or long-term debt divided by total debt plus accounts payable. We further define long-term leverage as long-term debt divided by total assets, and short-term leverage as short-term debt divided by total assets, accounts payable divided by total assets, or short-term debt plus accounts payable divided by total assets. Assets and Sales are in million RMB, where US\$1 = RMB8.2.

Significance at the $10 \%$ level.

** Idem, $5 \%$.

Id** $\quad 1 \%$

such research to further investigate how public governance quality in a heavily regulated environment affects firm financing choices.

Table 3 provides the basic statistics of the financing variables and the other firm characteristics of the sample firms. In Panels A and B, respectively, we report the pooled firm-year mean and median values of each of the variables during the three pre-event years, and the change over time in the variable, which is defined as the post-event three-year mean (median) value of the variable minus the pre-event three-year mean (median) value. The event year observations are excluded from the analysis, but the results would not change even if they were included. For firms with less than three years of data either before or after the corruption event we take the average of the available years before measuring the change in a variable. However, the overall results would not change if we alternatively included only those firms with a complete set of seven years of financial data.

Overall, these basic statistics suggest that the assets and sales levels of the event firms did not change significantly over time, although the event firms seem to have experienced slower growth in assets and sales than the non-event firms after the corruption event. In our subsequent regression analysis, we control for the possibility that changes in the financing behavior of the events firms around the corruption events are due to changes in fundamentals, rather than broken political connections.

The financial structures of the sample firms are comparable with those of the population of listed companies in China (Table 2). In terms of changes in the financing variables for the three sub-samples, we can make the following observations. First, firms in all three sub-samples experienced rises in their financial leverages over time, with the biggest increase taking place among non-event firms. Second, the mean debt maturity declines, but the magnitude is greater for event firms than for non-event firms. Third, there is almost no change in the mean long-term debt to assets ratio among the event firms, but increases by about 4.2 percent among the non-event firms. Fourth, the mean short-term debt and accounts payable ratios 
increase for both the event and non-event firms. Lastly, these observations hold true when we focus on the sub-sample of connected firms.

It is interesting that the overall reported patterns are not only found among the bribing firms but also among the connected firms that are not bribers and were not directly involved in the corruption cases. The changes in financing patterns of the connected firms are thus likely to be due to lost connections with the arrested bureaucrat, rather than due to the corruption event per se. This implication motivates us to separately examine this sub-sample of connected firms in the subsequent analysis.

\subsection{Univariate analysis of net over-time changes in capital structures}

We next examine the changes in the financing structures of the event firms following the corruption event net of the corresponding changes in the non-event firms. We define the net change in a financing variable as the difference in the change in a financing variable between the event firms (or the connected firms) and the non-event firms. The change in the financing variable of a firm is calculated as the three-year mean variable value after the corruption event minus the three-year mean value before the event.

As reported in columns 2 and 3 of Panel A of Table 4, both the mean and median net change in the leverage ratios of the event firms are negative and statistically significant (at the 1 percent level). These statistics suggest that the event firms experienced a significantly slower increase in debt financing than the non-event firms. The mean and median net changes in the debt maturity ratios are negative, but mostly insignificant. The net changes in the long-term debt to assets ratio are negative and highly significant, which suggests a decline in the long-term financing of the event firms relative to that of the non-event firms. The net changes in the short-term leverage ratio are also negative and significant, whereas the net changes in the accounts payable ratio are insignificant. We obtain similar results when we focus on the connected firms only (columns 4 and 5 ).

Panel B of Table 4 uses the matching firms as an alternative benchmark to compare the changes in the financing patterns of the event firms. The results are consistent with those of the non-event firms in Panel A. The financial leverage of the event firms, and in particular the long-term financial leverage, drops after the corruption event. However, the net changes in financial leverage become insignificant when the bribing firms are excluded (columns 4 and 5 ). The net changes in shortterm leverage are generally insignificant. The debt maturity of the event firms (both the bribing and the connected firms) is significantly shorter relative to that of the matching firms after the corruption event.

\subsection{Regression analysis}

We next perform regression analysis to examine whether the financing policies of the event firms evolve after the corruption event in the predicted manner, controlling for other factors that are known to affect leverage and debt maturity structures. The following regression models are employed ${ }^{14}$ :

Table 4

Differences in the change in capital structure and debt maturity around the corruption events between the event firms and control firms Panel A. Benchmarked against the non-event firms

\begin{tabular}{|c|c|c|c|c|}
\hline \multirow[t]{2}{*}{$\begin{array}{l}\text { Difference in the change in } \\
\text { leverage/Debt maturity }\end{array}$} & \multicolumn{2}{|c|}{$\begin{array}{l}\text { Between the event firms and } \\
\text { non-event firms }\end{array}$} & \multicolumn{2}{|c|}{$\begin{array}{l}\text { Between the connected and } \\
\text { non-event firms }\end{array}$} \\
\hline & Mean & Median & Mean & Median \\
\hline Total debt/Assets & $\begin{array}{l}-0.108^{* * *} \\
(-4.50)\end{array}$ & $\begin{array}{l}-0.095^{* * *} \\
(-4.56)\end{array}$ & $\begin{array}{l}-0.067^{* * *} \\
(-2.62)\end{array}$ & $\begin{array}{l}-0.039^{* * *} \\
(-2.54)\end{array}$ \\
\hline (Total debt + Accounts payable)/Assets & $\begin{array}{l}-0.127^{* * *} \\
(-4.73)\end{array}$ & $\begin{array}{l}-0.079^{* * *} \\
(-4.81)\end{array}$ & $\begin{array}{l}-0.075^{* *} \\
(-2.58)\end{array}$ & $\begin{array}{l}-0.033^{* * *} \\
(-2.38)\end{array}$ \\
\hline Long-term debt/Total debt & $\begin{array}{l}-0.048 \\
(-0.42)\end{array}$ & $\begin{array}{l}-0.120 \\
(-1.28)\end{array}$ & $\begin{array}{l}-0.069 \\
(-0.59)\end{array}$ & $\begin{array}{l}-0.205 \\
(-1.12)\end{array}$ \\
\hline Long-term debt/(Total debt + Accounts payable) & $\begin{array}{l}-0.036 \\
(-1.32)\end{array}$ & $\begin{array}{l}-0.080^{*} \\
(-1.70)\end{array}$ & $\begin{array}{l}-0.058^{*} \\
(-1.68)\end{array}$ & $\begin{array}{r}-0.112 \\
(-1.53)\end{array}$ \\
\hline Long-term debt/Assets & $\begin{array}{l}-0.043^{* * *} \\
(-4.25)\end{array}$ & $\begin{array}{l}-0.041^{* * *} \\
(-3.71)\end{array}$ & $\begin{array}{l}-0.048^{* * *} \\
(-3.76)\end{array}$ & $\begin{array}{l}-0.028^{* * *} \\
(-2.66)\end{array}$ \\
\hline Short-term debt/Assets & $\begin{array}{l}-0.064^{* * *} \\
(-3.72)\end{array}$ & $\begin{array}{l}-0.050^{* * *} \\
(-3.79)\end{array}$ & $\begin{array}{l}-0.018^{*} \\
(-1.78)\end{array}$ & $\begin{array}{l}-0.012^{*} \\
(-1.70)\end{array}$ \\
\hline Accounts payable/Assets & $\begin{array}{l}-0.017 \\
(-1.18)\end{array}$ & $\begin{array}{r}0.013 \\
(1.04)\end{array}$ & $\begin{array}{l}-0.015 \\
(-0.39)\end{array}$ & $\begin{array}{c}0.015 \\
(0.27)\end{array}$ \\
\hline
\end{tabular}

\footnotetext{
14 This "difference-in-differences" approach captures the different changes in financing pattern of the event firms and the control firms around the time of the corruption scandals.
} 
Panel B. Benchmarked against the matching firms

\begin{tabular}{|c|c|c|c|c|}
\hline \multirow[t]{2}{*}{$\begin{array}{l}\text { Difference in the change in } \\
\text { leverage/Debt maturity }\end{array}$} & \multicolumn{2}{|c|}{$\begin{array}{l}\text { Between the event firms and } \\
\text { matching firms }\end{array}$} & \multicolumn{2}{|c|}{$\begin{array}{l}\text { Between the connected firms and } \\
\text { matching firms }\end{array}$} \\
\hline & Mean & Median & Mean & Median \\
\hline Total debt/Assets & $\begin{array}{l}-0.078^{* * *} \\
(-2.21)\end{array}$ & $\begin{array}{l}-0.049^{* * *} \\
(-2.27)\end{array}$ & $\begin{array}{l}-0.043 \\
(-0.96)\end{array}$ & $\begin{array}{l}-0.027 \\
(-0.93)\end{array}$ \\
\hline$($ Total debt + Accounts payable)/ Assets & $\begin{array}{l}-0.074^{*} \\
(-1.77)\end{array}$ & $\begin{array}{l}-0.069 \\
(-1.50)\end{array}$ & $\begin{array}{l}-0.019 \\
(-0.35)\end{array}$ & $\begin{array}{r}0.013 \\
(0.04)\end{array}$ \\
\hline Long-term debt/Total debt & $\begin{array}{l}-0.049^{*} \\
(-1.77)\end{array}$ & $\begin{array}{l}-0.099^{* * *} \\
(-2.68)\end{array}$ & $\begin{array}{l}-0.028 \\
(-0.52)\end{array}$ & $\begin{array}{l}-0.058 \\
(-1.48)\end{array}$ \\
\hline Long-term debt/(Total debt + Accounts payable) & $\begin{array}{l}-0.069^{* * *} \\
(-2.35)\end{array}$ & $\begin{array}{l}-0.070^{* * *} \\
(-3.02)\end{array}$ & $\begin{array}{l}-0.073^{* *} \\
(-2.06)\end{array}$ & $\begin{array}{l}-0.072^{* * *} \\
(-2.13)\end{array}$ \\
\hline Long-term debt/Assets & $\begin{array}{l}-0.041^{* * *} \\
(-3.33)\end{array}$ & $\begin{array}{l}-0.017^{* * *} \\
(-3.31)\end{array}$ & $\begin{array}{l}-0.037^{* * *} \\
(-2.49)\end{array}$ & $\begin{array}{l}-0.008^{*} \\
(-1.85)\end{array}$ \\
\hline Short-term debt/Assets & $\begin{array}{l}-0.019 \\
(-0.74)\end{array}$ & $\begin{array}{c}-0.035 \\
(-1.30)\end{array}$ & $\begin{array}{r}0.013 \\
(0.40)\end{array}$ & $\begin{array}{r}0.013 \\
(0.04)\end{array}$ \\
\hline Accounts payable/Assets & $\begin{array}{l}-0.018 \\
(-0.84)\end{array}$ & $\begin{array}{c}0.008 \\
(1.32)\end{array}$ & $\begin{array}{c}0.003 \\
(0.12)\end{array}$ & $\begin{array}{c}0.017^{*} \\
(1.67)\end{array}$ \\
\hline (Short-term debt + Accounts payable)/Assets & $\begin{array}{l}-0.046 \\
(-0.85)\end{array}$ & $\begin{array}{c}-0.012 \\
(-0.76)\end{array}$ & $\begin{array}{l}-0.006 \\
(-0.09)\end{array}$ & $\begin{array}{l}0.030 \\
(0.72)\end{array}$ \\
\hline
\end{tabular}

This table reports the mean and median differences in the change in leverage and debt maturity ratios between the event firms and control firms. The event firms include the bribing firms and the connected firms. Bribing firms are those with senior managers or directors who bribed the bureaucrats in the corruption cases. Connected firms are those with senior managers or directors connected with the corrupt bureaucrats through current or past job affiliations, but who were not involved in the corruption case. Panel A reports the results using the non-event firms as the control firms. The non-event firms are other non-bribing, non-connected firms in the jurisdiction (province) of the bureaucrat. Panel B reports the results using matching firms as the benchmark for comparison. The matching firms are firms outside the jurisdiction of the corrupt bureaucrat jurisdiction (applicable to provincial corruption cases) but that have similar growth (market-to-book ratio), leverage (total debt over total assets), and industry affiliation to the event firm. The change in leverage and debt maturity variables are measured as the three-year mean values after the corruption event minus the three-year mean values before the event. The T-statistics to test the significance of the variables are reported in parentheses.

* Significance at the $10 \%$ level.

** Idem, $5 \%$.

Idem, $1 \%$.

$$
\begin{aligned}
\text { Financing }_{i t}= & \alpha_{0 i}+\alpha_{1} \text { Corrupt }_{i t}+\alpha_{2} \text { Post }_{i t}+\alpha_{3} \text { Corrupt }_{i t} * \text { Post }_{i t}+\alpha_{4} \text { Lass }_{i t}+\alpha_{5} \text { Lass }_{i t} * \text { Post }_{i t}+\alpha_{6} \text { Tangible }_{i t} \\
& +\alpha_{7} \text { Tangible }_{i t} * \text { Post }_{i t}+\alpha_{8} \text { Growth }_{i t}+\alpha_{9} \text { Growth }_{i t} * \text { Post }_{i t}+\alpha_{10} \text { Profit }_{i t}+\alpha_{11} \text { Profit }_{i t} * \text { Post }_{i t} \\
& +\alpha_{12} \text { SOE }_{i t}+\alpha_{11} \text { SOE }_{i t} * \text { Post }_{i t}+(\text { industry dummies })+\varepsilon_{i t},
\end{aligned}
$$

where Financing represents a host of leverage and debt maturity variables measured in the ways defined previously; Corrupt is a dummy variable that is equal to one if the firm is an event firm, and otherwise zero; Post is a dummy variable that is equal to one if the observation is after the year of the corruption event, and otherwise zero; Lass is the natural logarithm of total assets; Tangible is fixed assets over total assets; Growth is the market value of equity over book value of equity; Profit is net income over total assets; and SOE is a dummy variable equal to one if the firm's ultimate controlling owner is government, and otherwise zero. Corrupt $*$ Post is an interaction term to pick up the post-event changes in the financing pattern of the event firms relative to the control firms. We include the additional interaction terms Lass $*$ Post, Tangible $*$ Post, Growth $*$ Post, Profit $*$ Post, and SOE $*$ Post. Consistent with the literature, the inclusion of the assets, growth, profitability variables and their post-event interaction terms is to account for the possibility that some cross-sectional differences or temporal changes in corporate financial policy reflect differences or changes in other corporate fundamentals. In addition, the SOE dummy variable is included to control for any differences in financing behavior between state-owned firms and private firms. ${ }^{15}$ We also include a set of industry dummy variables to control for industry effects. In a different model specification, we include provincial GDP per capita and a provincial property rights protection index to account for potential regional institutional effects. Our results are robust to the inclusion of these additional control variables.

Annual firm observations from the third year before to the third year after the event, excluding the event year itself, are used in the regressions. As the residuals of a given firm are likely to be correlated within provinces and across years, we estimate the clustered standard errors (Peterson, 2005) by province and by firm to account for the dependence in the residuals. These clustered standard errors are in turn used to calculate the test statistics of the estimated coefficients in the regression models.

\subsubsection{The event firms}

Panel A of Table 5 reports the regression results with data from the event firms and the non-event firms. We initially focus on columns 2 to 5 . The estimated coefficients of the event-firm dummy (Corrupt) are insignificant in the regressions,

\footnotetext{
15 It is interesting to examine whether state-owned enterprises (SOEs) are more likely to be bribers or connected firms than private firms. Among the event firms, almost $85 \%$ are SOEs and the remaining are private firms. This ratio is comparable with the percentage of SOEs among all publicly traded companies in China in 2005. We therefore cannot determine whether SOEs are more or less likely to be bribers or connected with corrupt bureaucrats.
} 
whereas the coefficients of Post are negative and significant. We are particularly interested in the coefficient of the interaction term, Corrupt $*$ Post, which is negative and significant in each of the regressions. This suggests that the leverage and debt maturity levels of the event firms diminished substantially during and after the corruption event.

We next turn to the long- and short-term leverage regressions (columns 6-9). The coefficient of Corrupt is insignificant in the regressions, whereas the coefficient of Post is significantly negative in most of them. The coefficient of the interaction term, Corrupt $*$ Post, is negative and highly significant in the long-term leverage regression (column 6), but not in the shortterm leverage regression (columns 7-9), which suggests that the long-term financing ability of the event firms is weakened both during and after the corruption event. However, there is little evidence that the corruption event shifted the relative use of short-term debt and trade credit among the event firms.

The changes in financing pattern around the time of corruption events cannot be explained away by differences or changes in other corporate fundamentals, because these factors are controlled in the regressions. However, some of these factors may indeed have affected the financing patterns of the firms. Firm size (log assets) has a positive effect on leverage and debt maturity, and asset tangibility has a positive effect on debt maturity, or more specifically a positive effect on longterm debt but a negative effect on short-term debt and trade credit. This indicates that firms with few tangible assets tend to rely more on short-term financing than on long-term financing. Sales growth has a positive effect on leverage, and in particular short-term debt. Profit has a negative effect on leverage, but its effects on debt maturity are insignificant. These relations are largely consistent with those reported in the literature. The leverage ratios are unrelated to whether a firm is state controlled or private in the regressions.

Overall, the results in Panel A of Table 5 demonstrate the debt-financing capacity of the event firms, and in particular their long-term debt capacity, to be weaker following the corruption event.

Panel B of Table 5 provides regression results that are similar to those in Panel A, except that the non-event firm observations are replaced by the matching firm observations. Here, the dummy variable Corrupt is equal to one if an observation is from an event firm, and zero if the observation is from a matching firm. The results of the regressions remain similar to those in Panel A.

\subsubsection{Excluding the bribing firms}

It may be the case that the foregoing results are mostly accounted for by the bribing firms. It would therefore be useful to know whether the deteriorated debt-financing pattern associated with corruption events can be explained by lost political connections alone. We therefore we repeat the regression analysis using the connected firms only.

Table 5

Regression results for the role of rent seeking in the leverage and debt maturity ratios of the event firms Panel A. Benchmarked against the non-event firms

\begin{tabular}{|c|c|c|c|c|c|c|c|c|}
\hline $\begin{array}{l}\text { Dependent } \\
\text { variable }\end{array}$ & $\begin{array}{l}\text { Total debt/ } \\
\text { Assets }\end{array}$ & $\begin{array}{l}\text { (Total debt } \\
+\mathrm{AP}) / \\
\text { Assets }\end{array}$ & $\begin{array}{l}\text { Long-term } \\
\text { debt/ } \\
\text { Total debt }\end{array}$ & $\begin{array}{l}\text { Long-term } \\
\text { debt/(Total } \\
\text { debt }+\mathrm{AP})\end{array}$ & $\begin{array}{l}\text { Long term } \\
\text { debt/Assets }\end{array}$ & $\begin{array}{l}\text { Short-term } \\
\text { debt/Assets }\end{array}$ & $\mathrm{AP} /$ Assets & $\begin{array}{l}\text { (Short-term } \\
\text { debt + AP)/ } \\
\text { Assets }\end{array}$ \\
\hline Corrupt & $\begin{array}{c}0.008 \\
(0.40)\end{array}$ & $\begin{array}{c}0.008 \\
(0.40)\end{array}$ & $\begin{array}{c}0.055 \\
(1.60)\end{array}$ & $\begin{array}{l}0.034 \\
(1.11)\end{array}$ & $\begin{array}{c}0.006 \\
(0.60)\end{array}$ & $\begin{array}{c}0.003 \\
(0.18)\end{array}$ & $\begin{array}{c}-0.001 \\
(-0.04)\end{array}$ & $\begin{array}{c}0.002 \\
(0.09)\end{array}$ \\
\hline Post & $\begin{array}{l}-0.885^{* * *} \\
(-3.31)\end{array}$ & $\begin{array}{l}-1.286^{* * *} \\
(-4.21)\end{array}$ & $\begin{array}{l}-0.669^{*} \\
(-1.60)\end{array}$ & $\begin{array}{l}-0.377 \\
(-1.03)\end{array}$ & $\begin{array}{l}-0.234^{* * *} \\
(-2.33)\end{array}$ & $\begin{array}{c}0.418^{*} \\
(1.88)\end{array}$ & $\begin{array}{l}-0.439^{* * *} \\
(-4.09)\end{array}$ & $\begin{array}{l}-0.991^{* * *} \\
(-3.19)\end{array}$ \\
\hline Corrupt $*$ Post & $\begin{array}{l}-0.061^{* * *} \\
(-2.13)\end{array}$ & $\begin{array}{l}-0.059^{*} \\
(-1.76)\end{array}$ & $\begin{array}{l}-0.074^{*} \\
(-1.95)\end{array}$ & $\begin{array}{l}-0.062^{* *} \\
(-1.96)\end{array}$ & $\begin{array}{l}-0.031^{* * *} \\
(-2.78)\end{array}$ & $\begin{array}{l}-0.035 \\
(-1.39)\end{array}$ & $\begin{array}{c}0.005 \\
(0.47)\end{array}$ & $\begin{array}{l}-0.025 \\
(-0.66)\end{array}$ \\
\hline Lass & $\begin{array}{l}0.036^{* * *} \\
(2.92)\end{array}$ & $\begin{array}{l}0.044^{* * *} \\
(3.41)\end{array}$ & $\begin{array}{c}0.034 \\
(1.62)\end{array}$ & $\begin{array}{c}0.035^{*} \\
(1.84)\end{array}$ & $\begin{array}{l}0.019^{* * *} \\
(2.75)\end{array}$ & $\begin{array}{c}0.014 \\
(1.34)\end{array}$ & $\begin{array}{l}0.009^{* * *} \\
(2.23)\end{array}$ & $\begin{array}{l}0.025^{* * *} \\
(2.11)\end{array}$ \\
\hline Lass $*$ Post & $\begin{array}{l}0.049^{* * *} \\
(3.57)\end{array}$ & $\begin{array}{c}0.069 \\
(4.42)\end{array}$ & $\begin{array}{c}0.032 \\
(1.52)\end{array}$ & $\begin{array}{r}0.018 \\
(1.00)\end{array}$ & $\begin{array}{l}0.016^{* * *} \\
(2.30)\end{array}$ & $\begin{array}{l}0.027^{* * *} \\
(2.41)\end{array}$ & $\begin{array}{l}0.022^{* * *} \\
(4.12)\end{array}$ & $\begin{array}{l}0.057^{* * *} \\
(3.61)\end{array}$ \\
\hline Tangible & $\begin{array}{c}0.054 \\
(1.00)\end{array}$ & $\begin{array}{l}0.019 \\
(0.33)\end{array}$ & $\begin{array}{l}0.529^{* * *} \\
(4.27)\end{array}$ & $\begin{array}{l}0.508^{* * *} \\
(4.40)\end{array}$ & $\begin{array}{l}0.133^{* * *} \\
(3.50)\end{array}$ & $\begin{array}{l}-0.074^{*} \\
(-1.68)\end{array}$ & $\begin{array}{l}-0.072^{* * *} \\
(-3.13)\end{array}$ & $\begin{array}{l}-0.153^{* * *} \\
(-2.71)\end{array}$ \\
\hline Tangible $*$ Post & $\begin{array}{l}-0.016 \\
(-0.21)\end{array}$ & $\begin{array}{l}-0.036 \\
(-0.43)\end{array}$ & $\begin{array}{c}-0.093 \\
(-0.73)\end{array}$ & $\begin{array}{l}-0.108 \\
(-0.96)\end{array}$ & $\begin{array}{r}0.010 \\
(0.26)\end{array}$ & $\begin{array}{l}-0.093^{*} \\
(-1.86)\end{array}$ & $\begin{array}{l}-0.022 \\
(-0.85)\end{array}$ & $\begin{array}{l}-0.143^{* *} \\
(-2.00)\end{array}$ \\
\hline Sales growth & $\begin{array}{l}0.082^{* * *} \\
(3.73)\end{array}$ & $\begin{array}{l}0.094^{* * *} \\
(3.82)\end{array}$ & $\begin{array}{l}-0.030 \\
(-0.60)\end{array}$ & $\begin{array}{l}-0.007 \\
(-0.17)\end{array}$ & $\begin{array}{r}0.019 \\
(1.29)\end{array}$ & $\begin{array}{l}0.062^{* * *} \\
(3.29)\end{array}$ & $\begin{array}{r}0.014 \\
(1.38)\end{array}$ & $\begin{array}{l}0.079^{* * *} \\
(3.37)\end{array}$ \\
\hline Sales growth $*$ Post & $\begin{array}{c}0.052 \\
(1.17)\end{array}$ & $\begin{array}{c}0.081 \\
(1.62)\end{array}$ & $\begin{array}{c}0.019 \\
(0.34)\end{array}$ & $\begin{array}{l}-0.010 \\
(-0.22)\end{array}$ & $\begin{array}{c}0.001 \\
(0.05)\end{array}$ & $\begin{array}{c}0.024 \\
(0.63)\end{array}$ & $\begin{array}{c}0.033^{*} \\
(1.94)\end{array}$ & $\begin{array}{c}0.091^{*} \\
(1.76)\end{array}$ \\
\hline Profit & $\begin{array}{l}-1.545^{* * *} \\
(-8.19)\end{array}$ & $\begin{array}{l}-1.614^{* * *} \\
(-8.58)\end{array}$ & $\begin{array}{l}0.068 \\
(0.19)\end{array}$ & $\begin{array}{l}-0.338 \\
(-1.05)\end{array}$ & $\begin{array}{l}-0.301^{* * *} \\
(-2.70)\end{array}$ & $\begin{array}{l}-1.187^{* * *} \\
(-6.61)\end{array}$ & $\begin{array}{c}-0.074 \\
(-1.40)\end{array}$ & $\begin{array}{l}-1.257^{* * *} \\
(-6.57)\end{array}$ \\
\hline Profit $*$ Post & $\begin{array}{c}0.405^{*} \\
(1.79)\end{array}$ & $\begin{array}{c}0.462^{* *} \\
(1.98)\end{array}$ & $\begin{array}{c}0.277 \\
(0.67)\end{array}$ & $\begin{array}{c}0.385 \\
(1.08)\end{array}$ & $\begin{array}{c}0.144 \\
(1.19)\end{array}$ & $\begin{array}{c}0.255 \\
(1.33)\end{array}$ & $\begin{array}{c}0.070 \\
(0.95)\end{array}$ & $\begin{array}{c}0.299 \\
(1.32)\end{array}$ \\
\hline SOE & $\begin{array}{c}-0.021 \\
(-1.17)\end{array}$ & $\begin{array}{l}-0.019 \\
(-1.01)\end{array}$ & $\begin{array}{c}-0.032 \\
(-0.80)\end{array}$ & $\begin{array}{l}-0.039 \\
(-1.09)\end{array}$ & $\begin{array}{r}-0.011 \\
(-1.05)\end{array}$ & $\begin{array}{c}-0.013 \\
(-0.67)\end{array}$ & $\begin{array}{c}0.001 \\
(0.18)\end{array}$ & $\begin{array}{l}-0.013 \\
(-0.61)\end{array}$ \\
\hline SOE $*$ Post & $\begin{array}{l}-0.066^{* * *} \\
(-2.10)\end{array}$ & $\begin{array}{c}-0.061^{*} \\
(-1.72)\end{array}$ & $\begin{array}{c}0.022 \\
(0.53)\end{array}$ & $\begin{array}{r}0.010 \\
(0.27)\end{array}$ & $\begin{array}{r}-0.011 \\
(-0.82)\end{array}$ & $\begin{array}{c}-0.053^{*} \\
(-1.83)\end{array}$ & $\begin{array}{c}0.007 \\
(0.82)\end{array}$ & $\begin{array}{l}-0.060 \\
(-1.57)\end{array}$ \\
\hline$N$ & 1933 & 1933 & 1917 & 1917 & 1933 & 1933 & 1933 & 1933 \\
\hline Adjusted $R^{2}$ & $25.39 \%$ & $28.22 \%$ & $21.23 \%$ & $22.98 \%$ & $21.65 \%$ & $26.35 \%$ & $19.05 \%$ & $27.75 \%$ \\
\hline
\end{tabular}


Table 5 (continued)

Panel B. Benchmarked against the matching firms

\begin{tabular}{|c|c|c|c|c|c|c|c|c|}
\hline $\begin{array}{l}\text { Dependent } \\
\text { variable }\end{array}$ & $\begin{array}{l}\text { Total debt/ } \\
\text { Assets }\end{array}$ & $\begin{array}{l}\text { (Total debt } \\
+ \text { AP)/ } \\
\text { Assets }\end{array}$ & $\begin{array}{l}\text { Long-term } \\
\text { debt/ } \\
\text { Total debt }\end{array}$ & $\begin{array}{l}\text { Long-term } \\
\text { debt/(Total } \\
\text { debt + AP) }\end{array}$ & $\begin{array}{l}\text { Long term } \\
\text { debt/Assets }\end{array}$ & $\begin{array}{l}\text { Short-term } \\
\text { debt/Assets }\end{array}$ & AP/Assets & $\begin{array}{l}\text { (Short-term } \\
\text { debt + AP)/ } \\
\text { Assets }\end{array}$ \\
\hline Corrupt & $\begin{array}{l}0.029 \\
(1.18)\end{array}$ & $\begin{array}{c}0.029 \\
(1.00)\end{array}$ & $\begin{array}{c}0.073^{*} \\
(1.66)\end{array}$ & $\begin{array}{c}0.055 \\
(1.48)\end{array}$ & $\begin{array}{l}0.028^{* *} \\
(2.61)\end{array}$ & $\begin{array}{c}0.001 \\
(0.03)\end{array}$ & $\begin{array}{c}-0.000 \\
(0.02)\end{array}$ & $\begin{array}{c}0.001 \\
(0.04)\end{array}$ \\
\hline Post & $\begin{array}{c}-0.712^{*} \\
(1.75)\end{array}$ & $\begin{array}{c}-1.166^{* *} \\
(2.43)\end{array}$ & $\begin{array}{c}0.780 \\
(1.32)\end{array}$ & $\begin{array}{r}0.301 \\
(0.65)\end{array}$ & $\begin{array}{r}0.111 \\
(0.68)\end{array}$ & $\begin{array}{c}-0.811^{* *} \\
(2.56)\end{array}$ & $\begin{array}{c}-0.521 \\
(1.65)\end{array}$ & $\begin{array}{c}-1.273^{* *} \\
(2.23)\end{array}$ \\
\hline Corrupt $*$ Post & $\begin{array}{c}-0.067^{*} \\
(1.93)\end{array}$ & $\begin{array}{c}-0.052 \\
(1.27)\end{array}$ & $\begin{array}{c}-0.121^{* * *} \\
(2.73)\end{array}$ & $\begin{array}{c}-0.112^{* * *} \\
(2.97)\end{array}$ & $\begin{array}{c}-0.048^{* * *} \\
(3.66)\end{array}$ & $\begin{array}{c}-0.003 \\
(0.10)\end{array}$ & $\begin{array}{c}-0.003 \\
(0.14)\end{array}$ & $\begin{array}{r}-0.016 \\
(0.28)\end{array}$ \\
\hline Lass & $\begin{array}{l}0.036^{*} \\
(1.85)\end{array}$ & $\begin{array}{l}0.051^{* *} \\
(2.21)\end{array}$ & $\begin{array}{l}0.058^{* *} \\
(2.00)\end{array}$ & $\begin{array}{c}0.024 \\
(1.21)\end{array}$ & $\begin{array}{l}0.019^{* * *} \\
(3.09)\end{array}$ & $\begin{array}{r}0.011 \\
(0.63)\end{array}$ & $\begin{array}{l}0.026^{* *} \\
(2.14)\end{array}$ & $\begin{array}{c}0.055 \\
(1.49)\end{array}$ \\
\hline Lass $*$ Post & $\begin{array}{l}0.040^{* *} \\
(2.02)\end{array}$ & $\begin{array}{l}0.062^{* * *} \\
(2.72)\end{array}$ & $\begin{array}{c}-0.038 \\
(1.32)\end{array}$ & $\begin{array}{c}-0.013 \\
(0.58)\end{array}$ & $\begin{array}{c}-0.005 \\
(0.62)\end{array}$ & $\begin{array}{l}0.043^{* * *} \\
(2.73)\end{array}$ & $\begin{array}{l}0.026^{*} \\
(1.67)\end{array}$ & $\begin{array}{l}0.069^{* *} \\
(2.58)\end{array}$ \\
\hline Tangible & $\begin{array}{r}-0.071 \\
(0.78)\end{array}$ & $\begin{array}{r}-0.171 \\
(1.54)\end{array}$ & $\begin{array}{l}0.376^{* * *} \\
(2.65)\end{array}$ & $\begin{array}{l}0.395^{* * *} \\
(2.99)\end{array}$ & $\begin{array}{l}0.087^{* *} \\
(2.02)\end{array}$ & $\begin{array}{c}-0.175^{* *} \\
(2.29)\end{array}$ & $\begin{array}{c}-0.135^{* *} \\
(2.42)\end{array}$ & $\begin{array}{c}-0.362^{* * *} \\
(2.73)\end{array}$ \\
\hline Tangible $*$ Post & $\begin{array}{r}0.117 \\
(1.10)\end{array}$ & $\begin{array}{c}0.128 \\
(0.97)\end{array}$ & $\begin{array}{r}0.075 \\
(0.56)\end{array}$ & $\begin{array}{c}0.010 \\
(0.08)\end{array}$ & $\begin{array}{c}0.068^{*} \\
(1.72)\end{array}$ & $\begin{array}{r}-0.013 \\
(0.15)\end{array}$ & $\begin{array}{c}-0.032 \\
(0.44)\end{array}$ & $\begin{array}{c}-0.143 \\
(0.76)\end{array}$ \\
\hline Sales growth & $\begin{array}{c}0.058 \\
(1.56)\end{array}$ & $\begin{array}{c}0.052 \\
(1.18)\end{array}$ & $\begin{array}{r}-0.021 \\
(0.35)\end{array}$ & $\begin{array}{c}-0.005 \\
(0.11)\end{array}$ & $\begin{array}{r}0.017 \\
(0.91)\end{array}$ & $\begin{array}{r}0.037 \\
(1.34)\end{array}$ & $\begin{array}{c}-0.007 \\
(0.41)\end{array}$ & $\begin{array}{l}0.026 \\
(0.64)\end{array}$ \\
\hline Sales growth $*$ Post & 0.031 & 0.043 & -0.008 & -0.009 & -0.009 & 0.020 & 0.089 & 0.183 \\
\hline Profit & $\begin{array}{l}(0.45) \\
-1.526^{* * *}\end{array}$ & $\begin{array}{l}(0.55) \\
-1.641^{* * *}\end{array}$ & $\begin{array}{l}(0.10) \\
0.876^{* * *}\end{array}$ & $\begin{array}{c}(0.15) \\
0.521^{*}\end{array}$ & $\begin{array}{r}(0.38) \\
-0.015\end{array}$ & $\begin{array}{l}(0.35) \\
-1.483^{* * *}\end{array}$ & $\begin{array}{c}(1.30) \\
-0.124\end{array}$ & $\begin{array}{l}(1.44) \\
-1.605^{* * *}\end{array}$ \\
\hline Profit $*$ Post & $\begin{array}{l}(7.01) \\
0.824^{* * *}\end{array}$ & $\begin{array}{l}(5.94) \\
1.074\end{array}$ & $\begin{array}{c}(2.80) \\
-0.785^{*}\end{array}$ & $\begin{array}{c}(1.97) \\
-0.665^{*}\end{array}$ & $\begin{array}{c}(0.22) \\
-0.099\end{array}$ & $\begin{array}{c}(7.44) \\
0.892^{* * *}\end{array}$ & $\begin{array}{l}(1.22) \\
0.376^{* *}\end{array}$ & $\begin{array}{l}(5.73) \\
1.465^{* * *}\end{array}$ \\
\hline SOE & (2.79) & (3.05) & $(1.83)$ & $(1.73)$ & (0.94) & (3.52) & $(2.57)$ & $(3.51)$ \\
\hline $\mathrm{SOE} *$ Post & $\begin{array}{c}0.007 \\
(0.26) \\
-0.087^{* *}\end{array}$ & $\begin{array}{c}0.021 \\
(0.68) \\
-0.097^{* *}\end{array}$ & $\begin{array}{c}-0.077^{*} \\
(1.84) \\
0.025\end{array}$ & $\begin{array}{c}-0.063^{*} \\
(1.76) \\
-0.003\end{array}$ & $\begin{array}{r}-0.015 \\
(1.44) \\
-0.009\end{array}$ & $\begin{array}{c}0.021 \\
(0.90) \\
-0.066^{*}\end{array}$ & $\begin{array}{c}0.011 \\
(0.71) \\
-0.005\end{array}$ & $\begin{array}{r}0.027 \\
(0.67) \\
-0.067\end{array}$ \\
\hline$N$ & 792 & 792 & 792 & 792 & 792 & 792 & 792 & 792 \\
\hline Adjusted $R^{2}$ & $26 \%$ & $29 \%$ & $19 \%$ & $19 \%$ & $16 \%$ & $31 \%$ & $24 \%$ & $36 \%$ \\
\hline
\end{tabular}

This table reports the regression results for the impact of rent seeking on firm leverage and debt maturity. Annual observations of the event firms and control firms from three years before to three years after the event (excluding the event year) are included in the regressions. Panel A reports the results using the non-event firms as control firms. Panel B reports the results based on the event firms and the matching firms. The dependent variables are the various measures of leverage and debt maturity, as defined in Table 2. "AP" is accounts payable, or trade credit. The independent variables include the dummy variable "Corrupt" that equals 1 if the firm is an event firm, and otherwise 0 ; the dummy variable "Post" that equals 1 if an observation is after the event year, and 0 if it is before the event year; "Lass" measured as the log of assets; the interaction term of "Corrupt" and "Post;" tangible assets as a ratio of assets ("Tangible"); "Sales growth" measured as the percentage change in annual sales; and return on assets ("Profit"). "SOE" is a dummy variable that equals one for state-owned enterprises and zero for private firms. The interaction terms of Lass $*$ Post, Tangible $*$ Post, Sales growth $*$ Post, Profit $*$ Post, and $\mathrm{SOE} *$ Post are included to control for likely changes in firm characteristics that could affect the demand for financial capital. We include industry dummy variables in each of the regressions to control for industry effects. The standard errors are clustered by firm and province. The $T$-statistics adjusted by clustered standard errors are in parentheses.

* Significance at the $10 \%$ level.

** Idem, $5 \%$.

*** Idem, $1 \%$.

Panel A of Table 6 reports the results of a set of regressions based on the combined sample of the connected firms and the non-event firms. The dummy variable Corrupt is defined as one if the firm is a connected firm, and zero otherwise. We find that the estimated coefficient of the interaction term, Corrupt $*$ Post, is negative but insignificant in the leverage regressions (columns 2 and 3). The coefficient of the interaction term is negative and significant in the debt maturity and the long-term leverage regressions (columns 4, 5, and 6), but insignificant in the short-term debt and trade credit regressions (columns 6-8).

We repeat the regressions using the combined sample of connected firms and their matching firms. Panel B of Table 6 reports the regression results. The dummy variable Corrupt is equal to one if the observation is from a connected firm, and zero if it is from a matching firm. The results based on the matching firm benchmark are similar. Again, the regression results show the corruption event to have significant negative effects on the debt maturity and long-term leverage of connected firms, as revealed in the negative coefficients of the interaction term Corrupt * Post in columns 4, 5 and 6 .

As a robustness check, we repeat the analysis in Tables 5 and 6 but using mean ordinary least-squares regressions and including the pre- and post-event three-year mean values of the dependent and independent variables as observations. ${ }^{16}$ We obtain similar results to those from the regressions using annual data, and therefore do not tabulate the results.

The overall evidence in Tables 5 and 6 suggests the debt-financing capacity of the event firms to be substantially weaker after the corruption event, and that this is particularly so for their long-term debt financing strength. The results hold even if we control for other potential changes in corporate fundamentals and exclude the bribing firms from the analysis, which

16 We also use the median values in the regressions rather than the means and obtain similar results. 
suggests that the weakened debt-financing pattern is not simply a result of the corruption event, but is also related to lost political connections with the corrupt bureaucrat.

\subsection{Alternative interpretations}

The changes in financing patterns associated with corruption scandals are subject to several other interpretations. It is likely that bureaucrats allocate projects and contracts to politically connected firms, and that banks respond by providing better lending terms to these firms. It is therefore sufficient to have corruption in the real sector but not in the financial sector to generate the findings. The ideal means of separating the two hypotheses would be to focus on corruption cases that involve bank officers. However, we are limited by data because we only have two such cases. To address this issue, we examine whether the bribing and connected firms were more profitable than the non-event firms before the corruption scandals were exposed. As shown in Panels A and B of Table 9 which will be more fully discussed in Section 5, three years before the corruption scandals there was little difference in profitability between the event firms and the non-event firms. Moreover, in our regression analyses in Tables 5 and 6, the inclusion of several firm fundamental variables (profit and sales growth) should mitigate the concern that our key results are mostly driven by spurious correlations, such as banks lending to politically connected firms because they are more profitable or have better growth opportunities.

Another possible interpretation of our findings is that after the scandals broke, the banks were concerned about their reputation and hence reduced their loans to firms connected with the corrupt bureaucrats. The reduced financing capacity of the event firms following the scandals may therefore say little about whether "crony lending" existed before the scandals. To examine whether the banks preferentially lent to politically connected firms ex ante, we compare the financing variables between the event firms and the non-event firms in the third year before the corruption scandals erupted. We find that the event firms always have higher debt ratios in Year-3, and that the differences are statistically significant. We also examine these differences using regression. Basing on the cross-sectional data in Year-3, we regress the financing choice variables on the event-firm dummy variable while controlling for the other factors that influence financing choice. The dependent variables are the same as before, and the independent variables include Corrupt, Lass, Tangible, Sales Growth, SOE, and the industry dummy variables. The standard errors are clustered by province and firm, as before. As shown in Table 7, we find that the estimated coefficient of Corrupt is significantly positive in the debt maturity regressions (column 4) and the longterm leverage regressions (columns 5 and 6 ). The results are the same regardless of whether the non-event firms (Panel A) or the matching firms (Panel B) are used as the comparison benchmark. The estimated coefficient of Corrupt is positive and significant when the non-event firms are used as the benchmark (Panel A), but insignificant when the matching firms are used as the benchmark (Panel B). The insignificant result of the matching firm result is expected, as we use total leverage

Table 6

Regression results for the role of rent seeking in the leverage and debt maturity ratios of connected firms

Panel A. Benchmarked against the non-event firms

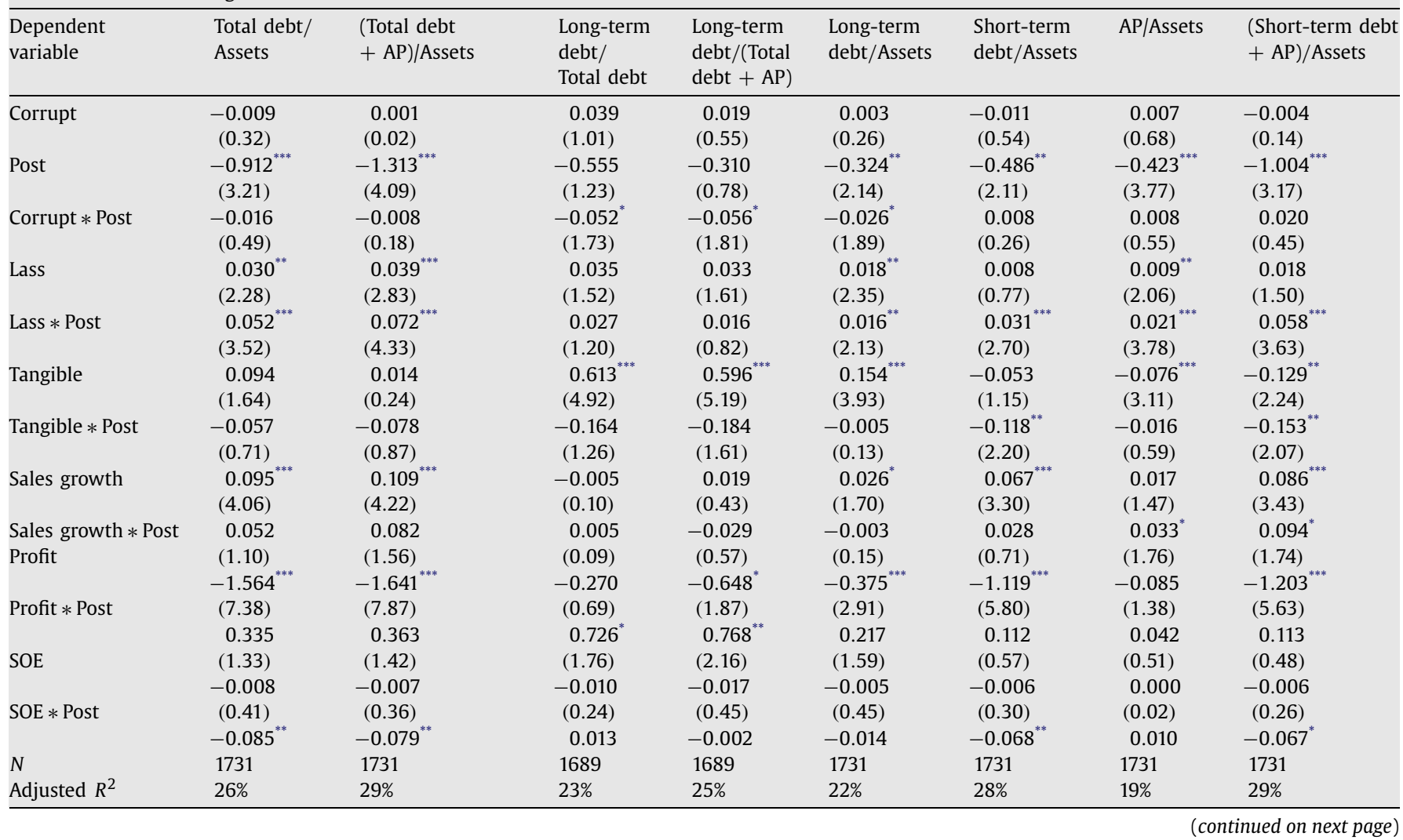


Table 6 (continued)

Panel B. Benchmarked against the matching firms

\begin{tabular}{|c|c|c|c|c|c|c|c|c|}
\hline $\begin{array}{l}\text { Dependent } \\
\text { variable }\end{array}$ & $\begin{array}{l}\text { Total debt/ } \\
\text { Assets }\end{array}$ & $\begin{array}{l}\text { (Total debt } \\
+\mathrm{AP}) / \text { Assets }\end{array}$ & $\begin{array}{l}\text { Long-term } \\
\text { debt/ } \\
\text { Total debt }\end{array}$ & $\begin{array}{l}\text { Long-term } \\
\text { debt/(Total } \\
\text { debt }+ \text { AP) }\end{array}$ & $\begin{array}{l}\text { Long-term } \\
\text { debt/Assets }\end{array}$ & $\begin{array}{l}\text { Short-term } \\
\text { debt/Assets }\end{array}$ & AP/Assets & $\begin{array}{l}\text { (Short-term debt } \\
+\mathrm{AP}) / \text { Assets }\end{array}$ \\
\hline \multirow[t]{2}{*}{ Corrupt } & 0.032 & 0.051 & 0.023 & 0.002 & $0.026^{*}$ & 0.008 & 0.017 & 0.024 \\
\hline & $(0.95)$ & $(1.20)$ & $(0.41)$ & $(0.04)$ & (1.88) & $(0.30)$ & (1.11) & $(0.56)$ \\
\hline \multirow[t]{2}{*}{ Post } & -0.317 & -0.271 & 0.326 & -0.363 & -0.001 & -0.323 & 0.116 & 0.306 \\
\hline & $(0.55)$ & $(0.39)$ & $(0.55)$ & $(0.78)$ & $(0.01)$ & $(0.66)$ & $(0.35)$ & $(0.27)$ \\
\hline \multirow[t]{2}{*}{ Corrupt $*$ Post } & -0.014 & 0.011 & $-0.053^{*}$ & $-0.053^{*}$ & $-0.033^{*}$ & 0.035 & 0.013 & 0.021 \\
\hline & $(0.33)$ & $(0.21)$ & (1.83) & (1.92) & (1.91) & $(0.97)$ & $(0.59)$ & $(0.29)$ \\
\hline \multirow[t]{2}{*}{ Lass } & $0.068^{* *}$ & $0.096^{* *}$ & 0.056 & 0.013 & $0.023^{* *}$ & 0.030 & $0.039^{*}$ & 0.104 \\
\hline & (2.10) & $(2.37)$ & (1.54) & $(0.41)$ & (2.15) & (1.10) & (1.90) & $(1.46)$ \\
\hline \multirow[t]{2}{*}{ Lass $*$ Post } & 0.021 & 0.017 & -0.016 & 0.021 & 0.000 & 0.022 & -0.006 & -0.008 \\
\hline & $(0.74)$ & $(0.51)$ & $(0.53)$ & $(0.87)$ & $(0.01)$ & $(0.92)$ & $(0.42)$ & $(0.15)$ \\
\hline \multirow[t]{2}{*}{ Tangible } & -0.103 & -0.221 & $0.667^{* * *}$ & $0.695^{* * *}$ & $0.124^{* *}$ & $-0.246^{* *}$ & $-0.130^{* *}$ & $-0.408^{* *}$ \\
\hline & $(0.79)$ & (1.35) & (3.56) & $(4.11)$ & (2.31) & (2.17) & $(2.13)$ & (2.18) \\
\hline \multirow[t]{2}{*}{ Tangible $*$ Post } & 0.094 & 0.175 & -0.147 & -0.242 & 0.035 & -0.016 & 0.056 & -0.055 \\
\hline & (0.69) & (1.01) & $(0.81)$ & (1.64) & $(0.73)$ & $(0.13)$ & $(0.67)$ & $(0.20)$ \\
\hline \multirow[t]{2}{*}{ Sales growth } & 0.055 & 0.062 & -0.085 & -0.041 & 0.019 & 0.031 & 0.006 & 0.026 \\
\hline & $(0.94)$ & $(0.86)$ & (1.15) & $(0.65)$ & (0.69) & $(0.78)$ & $(0.23)$ & $(0.39)$ \\
\hline \multirow[t]{2}{*}{ Sales growth $*$ Post } & 0.116 & 0.126 & 0.117 & 0.083 & 0.007 & 0.053 & 0.011 & 0.145 \\
\hline & $(1.15)$ & (1.09) & (1.03) & $(0.91)$ & $(0.21)$ & $(0.61)$ & $(0.31)$ & $(1.22)$ \\
\hline \multirow[t]{2}{*}{ Profit } & $-1.542^{* * *}$ & $-1.831^{* * *}$ & $0.741^{*}$ & 0.393 & -0.058 & $-1.442^{* * *}$ & $-0.326^{* *}$ & $-1.826^{* * *}$ \\
\hline & (4.95) & $(4.44)$ & (1.78) & (1.10) & $(0.58)$ & $(5.06)$ & $(2.30)$ & $(4.03)$ \\
\hline \multirow[t]{2}{*}{ Profit $*$ Post } & $0.954^{* *}$ & $1.330^{* * *}$ & -0.293 & -0.269 & -0.009 & $0.838^{* *}$ & $0.464^{* *}$ & $1.690^{* *}$ \\
\hline & $(2.42)$ & $(2.77)$ & $(0.72)$ & $(0.75)$ & $(0.09)$ & (2.37) & $(2.46)$ & $(2.44)$ \\
\hline \multirow[t]{2}{*}{ SOE } & 0.059 & 0.067 & -0.026 & -0.004 & -0.002 & $0.062^{* *}$ & 0.006 & 0.065 \\
\hline & $(1.58)$ & $(1.48)$ & $(0.49)$ & $(0.10)$ & $(0.20)$ & $(2.01)$ & $(0.35)$ & $(1.08)$ \\
\hline \multirow[t]{2}{*}{ SOE $*$ Post } & $-0.119^{* *}$ & $-0.127^{* *}$ & 0.036 & -0.007 & 0.002 & $-0.122^{* * *}$ & 0.004 & -0.083 \\
\hline & (2.33) & $(2.15)$ & $(0.56)$ & $(0.12)$ & $(0.13)$ & (2.66) & $(0.15)$ & $(0.91)$ \\
\hline$N$ & 406 & 406 & 382 & 382 & 406 & 406 & 406 & 406 \\
\hline Adjusted $R^{2}$ & $35 \%$ & $35 \%$ & $25 \%$ & $27 \%$ & $22 \%$ & $39 \%$ & $25 \%$ & $42 \%$ \\
\hline
\end{tabular}

This table reports the regression results for the impact of rent seeking on firm leverage and debt maturity. Annual observations of the connected firms (excluding the bribing firms) and control firms from three years before to three years after the event (excluding the event year) are included in the regressions. Panel A reports the results using the non-event firms as control firms. Panel B reports the results based on the connected firms and matching firms. The dependent variables are the various measures of leverage and debt maturity, as defined in Table 2. "AP" is accounts payable, or trade credit. The independent variables include the dummy variable "Corrupt" that equals 1 if the firm is an event firm, and otherwise 0; the dummy variable "Post" that equals 1 if an observation is after the event year, and 0 if it is before the event year; "Lass" measured as the log of assets; the interaction term of "Corrupt" and "Post;" tangible assets as a ratio of assets ("Tangible"); "Sales growth" measured as the percentage change in annual sales; and return on assets ("Profit"). "SOE" is a dummy variable that equals one for state-owned enterprises and zero for private firms. The interaction terms of Lass $*$ Post, Tangible $*$ Post, Sales growth $*$ Post, Profit $*$ Post, and SOE $*$ Post are included to control for likely changes in firm characteristics that could affect the demand for financial capital. We include industry dummy variables in each of the regressions to control for industry effects. The standard errors are clustered by firm and province. The T-statistics adjusted by clustered standard errors are in parentheses.

* Significance at the $10 \%$ level.

** Idem, $5 \%$

*** Idem, $1 \%$.

as one of our matching criteria. Overall, these results suggest that well before the influences of the corruption scandals were felt, the bribing and connected firms had superior access to bank loans, and in particular long-term loans. Hence, the reduction in bank lending to these firms following the corruption event is unlikely to be entirely driven by the incentive of the banks to protect their reputation.

\section{Capital structure change and performance}

We have established that there are relations consistent with the effects of rent seeking on capital structures. The bribing firms and connected firms had more debt, and in particular more long-term debt, in their capital structures before the arrest of the bureaucrat with whom they were connected. We next address whether the changes in firm financial policies are associated with changes in performance.

We perform an event study in which we estimate the cumulative abnormal stock returns of the firms around the initial public disclosure of the corruption news. The event day of a corruption scandal is identified as the first day that the public was informed about a bureaucrat's wrongdoing. Such notices can be Shuang Gui (a government detention measure that orders the person to confess his or her crimes at a specific location), arrest, or removal from the current position. The event days of the 23 corruption cases are reported in Table 1.

The standard event study methodology is used to investigate how the corruption news affected the stock prices of the firms. The abnormal return for security $i$ on event date $t$ is

$$
A R_{i, t}=R_{i, t}-E\left(R_{i, t} \mid I_{t}\right),
$$


Table 7

Regression analysis of debt ratios before the corruption events

Panel A. Event firms and non-event firms

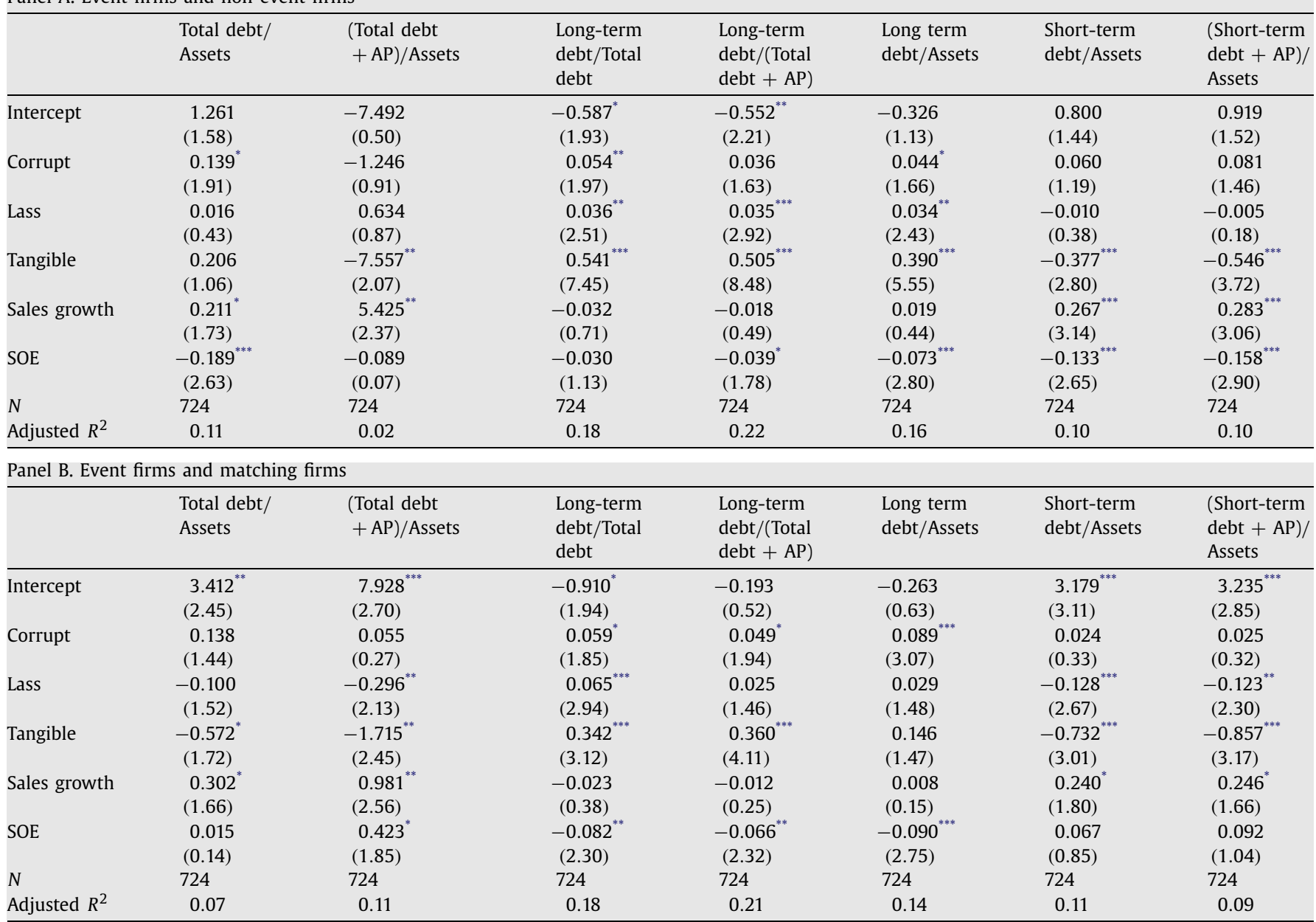

This table provides the regression analysis of the financing advantages of firms that bribed or were connected with corrupt bureaucrats three years before the corruption scandal. The dependent variables are total debt ratio, long-term debt ratio, short-term debt ratio (including trade credits), and maturity, which is the proportion of long-term debt to total debt. The independent variables are the same as those in Table 5 and Table 6 . Panel A reports the regression analyses based on event firms and non-event firms, where "Corrupt" equals one for event firms, and zero for non-event firms. Panel B reports the regression results for event firms and their matching firms. "Corrupt" in Panel B equals one for event firms and zero for the matching firms. We include industry dummy variables in each of the regressions to control for industry effects. The standard errors are clustered by firm and province. The T-statistics adjusted by clustered standard errors are in parentheses.

* Significance at the $10 \%$ level.

** Idem, $5 \%$.

**** Idem, $1 \%$.

where $A R_{i, t}, R_{i, t}$, and $E\left(R_{i, t} \mid I_{t}\right)$ are the abnormal, actual, and expected returns for time period $t$, respectively. $I_{t}$ is the information on which the expected return depends. There are two common ways to model the expected return: the mean adjusted returns model, in which $I_{t}$ is a constant, and the market model, in which $I_{t}$ is the market return. We employ both methods in our study. We use both equal- and value-weighted market returns when the market model is employed, and accumulate $A R_{i, t}$ to obtain the cumulative abnormal returns (CARs) using eight event windows of varying lengths that range from 60 days before to 60 days after the event day. Because the results are qualitatively similar, we report the results based on the market model and the value-weighted market return.

In Table 8, we stratify the sample into three terciles (bottom, middle, and top) based on the degree of change in the three-year mean debt to assets ratio before and after the corruption event. As shown in most of the event windows, more positive changes in leverage are associated with higher CARs, and more negative changes in leverage are associated with lower CARs. When we compare the mean and median difference in CARs between the top and bottom terciles, we find that most of the mean and median CARs in the top tercile are significantly higher than those in the bottom tercile. Moreover, $33 \%$ of the firms in the bottom tercile are either bribing firms or connected firms, compared with only $10 \%$ of the firms in the top tercile. These findings suggest that the weakened financing capacity caused by lost political connections has a negative impact on firm value.

Finally, we run a series of sensitivity analyses to check the robustness of our key results, as reported in Tables 5 to 8 . As described in Appendix D, these key results are robust to alternative definitions of event firms, different degrees of corruption punishment, survivorship bias, alternative scaling factors for the financing variables, and different lengths of event window. 
Table 8

Changes in leverage and stock market reactions around the corruption events

\begin{tabular}{|c|c|c|c|c|c|}
\hline & & Bottom tercile & Middle tercile & Top tercile & $\begin{array}{l}\text { Difference between top } \\
\text { and bottom tercile }\end{array}$ \\
\hline \multirow[t]{2}{*}{ Change in Total Leverage } & Mean & -0.049 & 0.153 & 0.445 & $0.445^{* * *}$ \\
\hline & Median & -0.002 & 0.173 & 0.386 & $0.388^{* * *}$ \\
\hline \multirow[t]{2}{*}{ CAR $(-60,60)$} & Mean & -0.036 & -0.057 & 0.043 & $0.080^{* * *}$ \\
\hline & Median & 0.004 & -0.025 & 0.019 & $0.015^{* * *}$ \\
\hline \multirow[t]{2}{*}{ CAR $(-40,40)$} & Mean & -0.036 & -0.042 & 0.044 & $0.081^{* * *}$ \\
\hline & Median & -0.008 & -0.051 & 0.033 & $0.041^{* * *}$ \\
\hline \multirow[t]{2}{*}{ CAR $(-20,20)$} & Mean & -0.013 & -0.025 & 0.021 & $0.034^{* *}$ \\
\hline & Median & -0.003 & -0.034 & 0.003 & $0.006^{* *}$ \\
\hline \multirow[t]{2}{*}{ CAR $(-10,10)$} & Mean & -0.014 & -0.008 & 0.011 & $0.025^{*}$ \\
\hline & Median & -0.001 & -0.024 & -0.005 & -0.004 \\
\hline \multirow[t]{2}{*}{ CAR $(-60,0)$} & Mean & -0.022 & -0.009 & 0.015 & $0.036^{*}$ \\
\hline & Median & -0.003 & -0.007 & -0.001 & 0.002 \\
\hline \multirow[t]{2}{*}{ CAR $(-40,0)$} & Mean & -0.012 & -0.001 & 0.022 & $0.033^{*}$ \\
\hline & Median & -0.001 & -0.017 & 0.010 & 0.011 \\
\hline \multirow[t]{2}{*}{ CAR $(-20,0)$} & Mean & -0.001 & 0.007 & 0.018 & $0.019^{*}$ \\
\hline & Median & -0.002 & 0.004 & -0.003 & 0.001 \\
\hline \multirow[t]{2}{*}{ CAR $(-10,0)$} & Mean & -0.004 & 0.008 & 0.005 & 0.009 \\
\hline & Median & -0.004 & -0.004 & -0.009 & -0.005 \\
\hline \# of firms in each tercile & & 124 & 124 & 125 & \\
\hline$\%$ of the event firms & & 33.07 & 19.9 & 10.0 & $-23.1^{* * *}$ \\
\hline
\end{tabular}

This table reports the mean and median cumulative abnormal returns (CARs) over various event windows for three sub-samples (the bottom tercile, middle tercile, and top tercile). The difference in the mean CAR between the top tercile and bottom tercile are also reported. The CARs are estimated by cumulating daily abnormal stock returns within various event windows that range from 60 days before to 60 days after the corruption event day. The event day is the first day of public disclosure of the bureaucrat's wrongdoing. The abnormal stock return is the stock return of a firm net of the value-weighted market return on the same day. The terciles are ranked by change in total leverage measured as the three-year mean leverage (debt to assets ratio) after the corruption event minus the three-year mean leverage before the event.

${ }^{*}$ Significance at the $10 \%$ level.

** Idem, 5\%.

**** Idem, $1 \%$.

\section{Does rent seeking facilitate capital allocation? ${ }^{17}$}

The empirical results thus far show that the access that the sample firms have to financial capital critically depends on their rent-seeking capacity. However, we are interested in finding out whether or not the rent seekers are also efficient firms who bribe or invest in relationships because they are affordable. Some argue that corruption can serve as grease to facilitate business transactions, a view that has been expressed in the business press and in the economics literature (Lui, 1985). It could therefore be the case that China's capital allocation system, although opaque, still manages to allocate financial capital to efficient firms. If so, then exposing corruption scandals has the side effect of punishing efficient firms. Another possibility is that the rent seekers tend to be firms that are uncompetitive in terms of management or production efficiency, but gain their competing edge through political connections or outright bribery. In this scenario, the problem of China's financial system is not merely one of social injustice, but also the misallocation of capital. Fighting corruption is in this case unambiguously desirable, because it will punish bad firms and promote good firms. ${ }^{18}$ A third possibility is that in a non-transparent capital allocation system everyone pays bribe to stay in the game, and getting caught is a random event. In this scenario, exposing scandals is an expected risk with no economic outcome.

We are not able to examine the issue fully in this paper, as our sample and data are specific to only a handful of corruption cases. Nevertheless, we do make an attempt to address the question by examining several performance measures of the event firms (relative to the non-event firms) both well before and well after (both three years) the corresponding corruption case broke, so that the performance measures are away from the direct influence of the corruption scandal. The performance measures capture the differences in profitability between the event and the non-event firms. ${ }^{19}$ If the event firms behave more as rent seekers because they are more efficient than the non-event firms, then their pre-event performance should be superior to, and their post-event performance no worse than, that of the non-event firms. ${ }^{20}$ However, if the event firms gain their competitive edge not from management or production efficiency but mostly from rent seeking, then we would expect that removing their political connections would lead to poorer performance relative to the non-event firms. If the randomness argument that the event and non-event firms are both rent seekers and that their rent-seeking

\footnotetext{
17 This section has benefited from the suggestions of Bernard Yeung.

18 There is a large amount of evidence that corruption slows down economic growth and domestic and foreign investment. See Bardhan (1997) and Aidt (2003) for an overview of this literature.

19 The differences in profitability reflect the differences in productivity and rent-seeking capability between the event and non-event firms.

20 We assume that the event and non-event firms are competing for an overlapping set of business opportunities, and that the scandals per se do not have a long-lasting impact on firm productivity.
} 
Table 9

Mean and median differences in performance between the event firms and non-event firms before and after the corruption events Panel A. Differences between the event firms and non-event firms

\begin{tabular}{|c|c|c|c|c|}
\hline & \multicolumn{2}{|c|}{ Three years before the scandal } & \multicolumn{2}{|c|}{ Three years after the scandal } \\
\hline & Mean & Median & Mean & Median \\
\hline $\mathrm{ROA}$ & $\begin{array}{c}0.012 \\
(1.06)\end{array}$ & $\begin{array}{c}0.042 \\
(1.08)\end{array}$ & $\begin{array}{l}-0.021^{* * *} \\
(-2.39)\end{array}$ & $\begin{array}{l}-0.007^{*} \\
(-1.95)\end{array}$ \\
\hline ROE & $\begin{array}{c}0.024 \\
(0.98)\end{array}$ & $\begin{array}{c}0.293 \\
(1.02)\end{array}$ & $\begin{array}{l}-0.041^{* * *} \\
(-2.26)\end{array}$ & $\begin{array}{l}-0.018^{*} \\
(-1.74)\end{array}$ \\
\hline Operating margin & $\begin{array}{c}0.042 \\
(1.27)\end{array}$ & $\begin{array}{c}0.216 \\
(1.15)\end{array}$ & $\begin{array}{l}-0.091^{* * *} \\
(-3.06)\end{array}$ & $\begin{array}{l}-0.037^{* * *} \\
(-2.44)\end{array}$ \\
\hline ROS & $\begin{array}{c}0.049 \\
(1.36)\end{array}$ & $\begin{array}{c}0.168 \\
(1.09)\end{array}$ & $\begin{array}{l}-0.077^{* * *} \\
(-2.66)\end{array}$ & $\begin{array}{c}-0.014 \\
(-1.55)\end{array}$ \\
\hline Market-to-book & $\begin{array}{l}0.244^{* * *} \\
(2.88)\end{array}$ & $\begin{array}{l}0.230^{* * *} \\
(2.43)\end{array}$ & $\begin{array}{c}0.046 \\
(0.34)\end{array}$ & $\begin{array}{c}0.140 \\
(0.16)\end{array}$ \\
\hline
\end{tabular}

Panel B. Differences between the connected firms and non-event firms

\begin{tabular}{|c|c|c|c|c|}
\hline & \multicolumn{2}{|c|}{ Three years before the scandal } & \multicolumn{2}{|c|}{ Three years after the scandal } \\
\hline & Mean & Median & Mean & Median \\
\hline $\mathrm{ROA}$ & $\begin{array}{l}-0.004 \\
(-0.28)\end{array}$ & $\begin{array}{l}-0.004 \\
(-0.29)\end{array}$ & $\begin{array}{l}-0.020^{* * *} \\
(-2.20)\end{array}$ & $\begin{array}{c}-0.007^{*} \\
(-1.67)\end{array}$ \\
\hline ROE & $\begin{array}{l}-0.008 \\
(-0.25)\end{array}$ & $\begin{array}{r}0.108 \\
(-0.29)\end{array}$ & $\begin{array}{l}-0.033 \\
(-1.45)\end{array}$ & $\begin{array}{l}-0.024 \\
(-1.55)\end{array}$ \\
\hline Operating margin & $\begin{array}{l}-0.006 \\
(-0.14)\end{array}$ & $\begin{array}{l}-0.052 \\
(-0.00)\end{array}$ & $\begin{array}{l}-0.078^{* *} \\
(-1.96)\end{array}$ & $\begin{array}{c}-0.037^{*} \\
(-1.71)\end{array}$ \\
\hline ROS & $\begin{array}{c}0.004 \\
(0.08)\end{array}$ & $\begin{array}{l}-0.057 \\
(-0.13)\end{array}$ & $\begin{array}{l}-0.084^{* * *} \\
(-2.18)\end{array}$ & $\begin{array}{l}-0.019 \\
(-0.16)\end{array}$ \\
\hline Market-to-book & $\begin{array}{c}0.144 \\
(1.31)\end{array}$ & $\begin{array}{c}0.133 \\
(0.76)\end{array}$ & $\begin{array}{l}-0.031 \\
(-0.18)\end{array}$ & $\begin{array}{l}-0.060 \\
(-0.19)\end{array}$ \\
\hline
\end{tabular}

This table reports the mean and median performance differences between the event firms and non-event firms (Panel A), and between the connected firms and non-event firms (Panel B), in the third year before to the corruption event year and the third year after the corruption event year. ROA is return on assets; ROE is return on equity; Operating Margin is operating income divided by sales; ROS is return on sales; and Market-to-book ratio is the market value of equity divided by the book value of equity.

* Significance at the $10 \%$ level.

** Idem, $5 \%$.

*** Idem, $1 \%$.

activities have little to do with their management or production efficiency is true, then there should be little difference in their performance before the scandals, although the event firms may underperform the non-event firms after the scandals.

Table 9 presents the differences in mean and median performance measures between the event firms and non-event firms. Performance is measured alternatively by return on assets (ROA), return on equity (ROE), operating margin (operating income divided by sales), return on sales (ROS), and the market to book ratio (the market value of equity divided by the book value of equity). These performance measures are calculated for each of the event and non-event firms at the fiscal year-end of the third year before and the third year after the corresponding corruption event year. Panel A shows the mean and median between-group performance differences before the events to be generally positive, but insignificantly so except for the market-to-book ratio. ${ }^{21}$ After the corruption event, the performance differences are mostly negative and statistically significant, except again for the market-to-book ratio, which shows insignificantly positive values. In Panel B we remove the bribing firms and focus on a comparison of the connected firms and the non-event firms. We find that none of the measures reveals a significant difference in performance between the connected and non-event firms before the scandals, but after the scandals the connected firms underperformed the non-event firms, and significantly so in terms of ROA, ROS, and operating margin.

The statistics in Table 9 suggest that the event firms did not significantly outperform the non-event firms before the corruption scandals were exposed, but substantially underperformed them after the scandals had broken. This evidence is inconsistent with the view that efficient firms pay bribes or build political connections to gain access to financial capital. Rather, it is more consistent with the second scenario that event firms gain financing and possibly other competitive advantages primarily from rent seeking, because their performance was clearly worse than the non-connected firms long after the corruption event. However, we are unable to reject the third randomness view that rent seeking is pervasive among both event and non-event firms.

Overall, we do not find evidence that financial capital is allocated to rent seekers because they are efficient firms. In contrast, we find that rent-seeking firms become uncompetitive once their political connections are removed following

21 The event firms have higher market-to-book ratios, which indicates that they may have greater growth opportunities due to their political connections. 
the exposure of corruption. A reason why corruption fails to grease but only serves to clog business transactions is that government regulations are endogenous to bureaucrat incentives to seek rents (Shleifer and Vishny, 1994, 1998). A lessthan-benevolent bureaucrat can create red tape to expropriate business rents at the expense of efficiency. Consistent with this, Kaufmann and Wei (1998) report that corruption is associated with increased, rather than decreased, business costs.

\section{Conclusion}

We examine the impact of corruption and rent seeking on corporate financing behavior through an event study. We identify publicly listed firms that bribed or were connected with corrupt high-level government bureaucrats. We find the financial leverage of both the bribers and the connected firms to be significantly less than that of the control firms following the arrest of the corrupt bureaucrat with whom they had connections. These relative declines in leverage are mainly due to decreases in long-term debt, as the relative levels of short-term debt are less significantly changed. Consistent with this, the debt maturity of the bribing firms and the connected firms is significantly shorter subsequent to the capture of the relevant corrupt bureaucrat. These results suggest that being connected with corrupt bureaucrats provides firms with a comparative advantage in access to debt, and in particular long-term debt. However, this debt-financing advantage disappears when the connections are broken due to the arrest of such bureaucrats.

We also examine whether any of the lost financing advantages are reflected in poor firm performance, a prediction that is confirmed in our study of stock return patterns around the time of corruption events. The results suggest that stock markets discount the value of firms with reduced financial leverage (or leverage that does not increase as much as that of other firms) around the corruption events. Finally, we find little evidence from the sample to suggest that rent seeking facilitates capital allocation in China.

Our study makes several contributions to the literature. First, it provides evidence of the importance of institutional factors in shaping corporate financing choices, which is beginning to draw the attention of researchers. Second, our singlecountry setting and the time-serial empirical design provide robust evidence that is subject to smaller endogeneity and omitted variable problems than occur in cross-sectional studies. Third, the results should help policy makers to gauge the importance of fighting corruption and building market-supporting institutions. The evidence from China should also prove useful for other emerging markets plagued by similar institutional problems. Fourth, previous studies (e.g., Bradley et al., 1984) find that firms in regulated sectors tend to have higher financial leverage than less regulated firms. Our findings from China's heavily regulated environment raise the possibility that the higher debt loads of regulated firms are not only attributable to their assets, but also to the self-interest of bureaucrats. We call for future research into this issue.

\section{Appendix A. A corrupt bureaucrat and his allies}

This example illustrates the process of identifying bribing and connected firms in a corruption case. A criminal case was initially exposed in Jiangshu province in 1994, in which it was reported that Wuxi Xing Xing Industrial Ltd. illegally took substantial deposits (RMB3.2 billion) from the public. During the investigation, it was found that Li Ming (secretary of the Beijing mayor Li Qiyan) was involved in the scandal. Li Ming then turned evidence on Zhou Beifang (chairman and CEO of Shougang Holding HK Ltd.), Chen Jian (secretary of Chen Xitong, the secretary of the Communist Party of China in Beijing), and Chen Xiaotong (son of Chen Xitong). In early 1995, Zhou Beifang, Chen Jian, and Chen Xiaotong were arrested. On April 5, 1995, Wang Baosheng, vice mayor of Beijing, committed suicide. Over the next year, tens of Beijing officials were

\begin{tabular}{|c|c|c|c|}
\hline Firm name & Listed market & Connection type & Note \\
\hline Beijing Development & HK & Colleague and Briber & $\begin{array}{l}\text { Gao Qiming (chairman) was an ex-secretary of Chen Xitong. In addition, } \\
\text { three other officials from the Beijing government sat on the company's } \\
\text { board. }\end{array}$ \\
\hline Shougang Concord Century & HK & Briber & $\begin{array}{l}\text { Zhou Beifang, chairman and CEO of the controlling shareholder (Shougang } \\
\text { Holding) of the company, was a conspirator and briber of Chen Xitong. }\end{array}$ \\
\hline Shougang Concord Technology & HK & Briber & $\begin{array}{l}\text { Zhou Beifang, chairman and CEO of the controlling shareholder (Shougang } \\
\text { Holding) of the company, was a conspirator and briber of Chen Xitong. }\end{array}$ \\
\hline Shougang Concord International & HK & Briber & $\begin{array}{l}\text { Zhou Beifang (chairman and CEO) was a conspirator and briber of Chen } \mathrm{Xi} \text { - } \\
\text { tong. }\end{array}$ \\
\hline Shougang Concord Grand & HK & Briber & $\begin{array}{l}\text { Zhou Beifang (chairman and CEO) was a conspirator and briber of Chen Xi- } \\
\text { tong. }\end{array}$ \\
\hline Beiren Printing & $\begin{array}{l}\text { HK } \\
\text { Shanghai }\end{array}$ & Colleague & Zhang Peng (director) was the vice mayor of Beijing City. \\
\hline Beijing Auto & Shanghai & Colleague & $\begin{array}{l}\text { Zhu Lining (director) was the vice-president of the Beijing Municipal Finance } \\
\text { Bureau. }\end{array}$ \\
\hline Beijing Urban-Rural & Shanghai & Colleague & Both its chairman and vice-chairman had worked in the Beijing government. \\
\hline Beijing Tianqiao & Shanghai & Unconnected firm & Not applicable \\
\hline Beijing Tianlong & Shanghai & Unconnected firm & Not applicable \\
\hline Wangfujing Store & Shanghai & Unconnected firm & Not applicable \\
\hline
\end{tabular}


arrested. On July 31, 1998, Chen Xitong was finally sentenced to 16 years' imprisonment for corruption. The following table reports our classification of the bribers, the connected firms, and the unconnected firms in this corruption case. There were a total of 11 publicly traded companies in Beijing around the time of the corruption event. We are able to identify 5 bribers (one also have job connection), 3 connected (but non-bribing) firms, and 3 unconnected firms.

\section{Appendix B. Summary of the corruption cases}

Wang Huizhong was Vice-Governor of Anhui province. Between September 1994 and March 2001, he accepted 20 bribes that were worth RMB5,171,000, and could not provide legitimate sources for assets that were worth RMB4,800,000. Wang received the death penalty in 2003 .

Source: Communiqué of the Central Commission for Discipline Inspection of the Communist Party of China [No. 8 2003].

Liu Jinbao was Vice-Chairman and CEO of the Bank of China (HK). He embezzled RMB14.48 million (US\$1.75 million), of which he personally pocketed RMB7.72 million. He also received bribes that amounted to RMB1.43 million and was unable to account for RMB14.78 million in personal assets.

Source: Xinhua News, August 12, 2005.

Wang Xuebin was the CEO of the China Construction Bank. He was sentenced to 12 years of imprisonment in 2002 on a charge of accepting bribes that were worth RMB1.15 million (US\$139,000) between 1993 and 2001.

Source: Communiqué of the Central Commission for Discipline Inspection of the Communist Party of China [No. 8 2002].

Chen Xitong was the CPC Secretary of Beijing. Between July 1991 and November 1994, he accepted gifts that were worth RMB 555,956. He ordered his secretary to build two villas that were worth RMB35,210,000 for his personal use, and also spent RMB1,050,000 on personal entertainment. He was sentenced to 16 years of imprisonment in 1998.

Source: Communiqué of the Supreme Court [No. 266, 1998].

Li Daqiang was the Vice-Governor of Hubei province. In November 1995, he received 10,000 shares of stock in Hubei Xinfua Incorporated Company worth RMB100,100. He also accepted bribes worth RMB25,000 from Hubei Petroleum company, and between 1994 and 1998 pocketed gifts that were worth RMB80,000 and US\$10,000 from a manager of a stock brokerage house. Li was dismissed from his post and the CPC in 2000.

Source: Xinhua News, September 25, 2000.

Xu Penghang was the Vice-Chairman of the National Defense Technology Commission and the National Economics and Trade Commissions. In December 1993, he promised Hubei Huangshi Kangshai Group that it could be listed on the stock exchange. In return, his wife and daughter received 120,100 shares in the firm. In August 1996, Xu's family sold the shares at RMB10 each, pocketing a profit of RMB1,130,000. Xu was dismissed from his post in 2000.

Source: Xinhua News, October 11, 2000.

Shi Zhaobin was the Vice-CPC Secretary of Fujian province. He helped the Fujian Petroleum Company to obtain favorable deals, and between July 1994 and August 1999 accepted bribes that were worth RMB599,897. He was dismissed from his post and the CPC in 2001.

Source: Communiqué of the Sixth Meeting of the Fifteenth Central Committee of the Chinese Communist Party, September 26, 2001.

Xu Binsong was the Vice-Chairman of Guangxi Municipality. He helped several private businessmen, including the Yuling Cements Group and Guixin Seed Company, to obtain governmental projects, business licenses, and local government subsidies. Between August 1995 and June 1997 he accepted seven bribes that amounted to RMB550,000, and also accepted gifts that were worth RMB100,000. He was sentenced to life imprisonment in 1999.

Source: Communiqué of the Central Commission for Discipline Inspection of the Communist Party of China [No. 11 1998].

Chen Kejie was the Chairman of the Guangxi Municipality. In November 1994 he accepted bribes that were worth RMB20,000,000 for helping to transfer the controlling rights of the Yixin Real Estate Development Company from the Guangxi International Economic and Technology Cooperation Company to the Guangxi government. He also accepted bribes through his mistress that amounted to RMB9,000,000 and HK\$8,040,000 for helping Guangxi Guixin Development Company to obtain projects between 1996 and 1997, and accepted various gifts between July 1994 and 1997 that were worth RMB550,000. Chan received the death penalty in 2000 .

Source: Source: Communiqué of the Supreme Court [No. 434, 2000].

Liu Zhibin was the Vice-Chairman of Guangxi Municipality. In 1997, Liu accepted bribes that were worth RMB300,000, HK\$80,000, and US\$18,000 for helping a businessman to avoid taxes that were worth RMB690,000. Between 1993 and 1999, Liu accepted bribes that amounted to RMB170,000 and US $\$ 2,000$ for helping a company to obtain a waiver from a utility bill that was worth RMB20,000,000. His wife collected bribes on his behalf that were worth RMB110,000 and HK\$13,000 for promoting three subordinates. Liu accepted further bribes that amounted to RMB832,000. He was sentenced to 15 years' imprisonment in 2002.

Source: Communiqué of the Nanning Middle Court, June 24, 2002.

Wang Qinglu was the Vice-Chairman of the PPCC in Guangxi. He granted deals to businessman Yang of Beihai Haitai Investment Corporation, from whom his wife and son collected bribes that were worth HK\$180,000 and RMB230,000. Wang was relieved of his duties and dismissed from the CPC in 2001.

Source: Xinhua News, February 21, 2001.

Liu Changgui was the Vice-Governor of Guizhou province. He helped Guizhou Kaida Real Estate Development Company and Guizhou Jundian Construction Group to obtain projects, and accepted bribes that were worth RMB1,100,000 and US\$30,000. He was also unable to account for RMB1.76 million in personal assets. He was sentenced to 11 years' imprisonment in 2004.

Source: Communiqué of the Zhunyi Middle Court [No. 12 2004]. 
Liu Fangren was the CPC Secretary and PC Chairman of Guizhou province. He helped Guizhou Jundian Construction Group to obtain a loan of RMB5 million, in return accepting bribes that were worth RMB1,490,000. He also assisted Guizhou Tongda Decoration Company to obtain decoration projects of RMB80 million, and accepted bribes that were worth RMB120,000 and US\$19,000 from businessman Chen. He was sentenced to life imprisonment in 2004.

Source: Communiqué of the Central Commission for Discipline Inspection of the Communist Party of China [No. 12003 ].

Xin Yejiang was the Vice-PC Chairman of Hainan province. He accepted 60,000 shares in the Hainan Pharmaceutical Corporation for helping it to obtain an IPO quota, and sold the shares for RMB193,194 after the firm was listed. He was sentenced to five years' imprisonment in 1998.

Source: Communiqué of the Central Commission for Discipline Inspection of the Communist Party of China [No. 1 1998].

Jiang Dianwu was the Vice-PC Chairman of Hebei province. He accepted bribes that worth HK\$15,000 and a gift that was worth RMB11,600 from a Hong Kong businesswoman in December 1993. In return, he granted the businesswoman the right to operate a gambling business in a resort in the province. He also accepted RMB50,000 in 1993 and RMB100,000 in 1995 from businessman Zhu of Yianzhao Textile Company. He was sentenced to 10 years' imprisonment in 1998.

Source: Communiqué of the Central Commission for Discipline Inspection of the Communist Party of China [No. 9 1998].

Chen Weigao was the CPC Secretary and PC Chairman of Hebei province. He abused his power and allowed his family members to commit various crimes, and accepted bribes. He was dismissed from the CPC in 2003.

Source: Xinhua News, August 9, 2003.

Cong Fukui was the Vice-Governor of Hebei province. He helped Hong Kong Shengkang International Company to extend the maturity of a US\$3 million loan from July 1997 to 1998. He also assisted Hebei Yutong Enterprise Limited to obtain a loan of RMB45 million from 1998 to May 2000. In return, between from April 1996 and June 2000 he accepted bribes that were worth RMB14,150,000 and HK\$340,000, and gifts that were worth HK\$52,000. He received the death penalty in 2001.

Source: Source: Communiqué of the Hebei Supreme Court, May 17, 2001.

Meng Qingping was the Vice-Governor of Hubei province. He granted usage rights on 10.94 acres of land to a businesswoman from the Fujian Huian Shanyao Construction Company in August 1989, and also helped a businessman from the Hainan Qianghai Company to obtain 20 acres of land in 1992. His wife collected bribes of RMB140,000 and HK\$100,000 between 1989 and 1993. Meng was sentenced to 10 years' imprisonment in 1999.

Source: Communiqué of the Central Commission for Discipline Inspection of the Communist Party of China [No. 16 1998].

Hu Changqing was the Vice-Governor of Jiangxi province. He helped eight businessmen from Jianoxi Oute Group, Nanchang Haiwei Limited, Golden Sunshine Group, Jiangxi Weimeng Group, Jiangxi General Metal Material, and Fujian Qunrong Real Estate Development Company to obtain various projects, bank loans, and business licenses. In return, he accepted bribes that amounted to RMB1,530,000, HK\$750,000, and US\$35,000, and luxury gifts, such as watches and diamond rings, that were worth RMB1,400,000. He received the death penalty in 2000.

Source: Communique of the Central Commission for Discipline Inspection of the Communist Party of China [No. 12 1999].

Mu TuoXing was the Vice-Governor of Liaoning province. He granted a wild zoo project to Shengyang Shenjing Golf Club, and promoted the general manager of Shengyang Bus Group to the head of the Shengyang Transportation Bureau. He helped Liaoning Real Estate Development Company to obtain projects, and in return accepted bribes between April 1993 and December 2000 that were worth RMB6,641,400. He was unable to account for RMB2.695 million in personal assets, and also helped family members to obtain projects. He received the death penalty in 2001.

Source: Communiqué of the Central Commission for Discipline Inspection of the Communist Party of China [No. 4 2001].

Aman Haji was the Vice-Governor of Xingjiang. He was accused of accepting huge bribes and abusing his power. His case is still under investigation.

Source: Xinhua News, November 24, 2005.

Li Jiating was the Vice CPC Secretary and Governor of Yunnan province. Between 1994 and July 2000, he accepted bribes that were worth RMB11,000,000. He received the death penalty in 2003.

Source: Communique of the Sixth Meeting of the Fifteenth Central Committee of the Chinese Communist Party, September 26, 2001 and Xinhua News, June 20, 2003.

Xu Yunhong was the Vice-Governor of Zhejiang province. He helped Ningbao International Trust and Investment Corporation to obtain loans, and also committed malfeasance and caused losses of government assets worth RMB1.2 billion. He forced Ningbao Daily to purchase the Huahong International Center building from a private businessman Zhong, which caused a huge economic loss for Ningbao Daily. In return, his son accepted bribes that were worth RMB5,690,000, HK\$120,000, US\$25,000, and a villa that was worth RMB850,000. He was sentenced to 10 years' imprisonment in 2000 .

Source: Communiqué of the Hangzhou Supreme Court [No. 110, 2000].

\section{Appendix C. An example of the sample matching method}

Yunan Aluminum Co. (stock code is 000807) is identified as being connected with the former governor of Yunan province Jiating Li, who was involved in a corruption scandal in 2001. To identify a matching firm for Yunan Aluminum, we first identify its industry affiliation, market-to-book ratio, and total debt ratio in 1998, three years before the event. Yunan Aluminum operates in the medal and aluminum processing and manufacturing industry. In 1998, there were 12 companies (excluding Yunan Aluminum) primarily operating in the same industry. We exclude four of the 12 firms that are already in our sample of 393 firms. We then calculate the market-to-book ratios and total debt ratios for each of the remaining eight firms. Yunan Aluminum has a market-to-book ratio of 1.63 and a total debt ratio of $46 \%$. Among the eight firms, Jiaozuo 
Wanfang Co. (stock code 000612), a local government owned firm, has a market-to-book ratio (1.44) and total debt ratio (39\%) closest to those of Yunan Aluminum. We therefore choose Jiaozuo Wanfang as the matching firm for Yunan Aluminum.

\section{Appendix D. Additional robustness tests}

We run a battery of sensitivity analyses to check the robustness of our key results. First, we redefine our event firms. If a firm is identified as a briber or a connected firm in a corruption case, then it is classified as an event firm in every other corruption case that occurred in the same province. Previously, it was classified as an event firm only in the corruption case in which it was directly involved. The new definition gives us 102 event firms, of which 51 are connected firms. Our analyses based on the new definition give qualitatively similar results.

We next examine whether different degrees of punishment in the corruption cases affect the financing behavior of the event firms differently. We include those cases in which bureaucrats were sent to prison or executed, and exclude those cases that ended in less serious punishment, such as dismissal from service or expulsion from the party. Our overall results remain similar.

Firms may be delisted from trading, hence creating a survivorship bias in our analysis. We find only five firms that were delisted one or two years after the events. Among the five firms, two firms are event firms, and the other three are non-event firms. The small number of delisted firms does not cause systematic bias in our analysis.

To check if our results are sensitive to the choice of scaling factor, we use total sales as an alternative, and the results remain intact. We also perform regression analysis on the percentage changes in the level of total debt, long-term debt, and short-term debt, and obtain similar results.

We also choose different event windows to examine the changes in firm financing. We rerun the financing regressions (Tables 4-6) using paired data from year -1 with year +1 , year -2 with year +2 , or year -3 with year +3 . Again, the results are similar and consistent.

Finally, we examine the patterns of rights offerings and seasonal equity offerings around the time of the corruption scandals, but find insignificant differences in the equity financing patterns.

\section{References}

Acemoglu, D., Johnson, S., 2005. Unbundling institutions. Journal of Political Economy 113, 949-995.

Aidt, T.S., 2003. Economic analysis of corruption: A survey. Economic Journal 113, 632-652.

Allen, F., Qian, J., Qian, M.J., 2005a. Law, finance, and economic growth in China. Journal of Financial Economics 77, 57-116.

Allen, F., Qian, J., Qian, M.J., 2005b. China's financial system: Past, present, and future. In: Brandt, L., Rawski, T. (Eds.), China's Great Economic Transformation. Cambridge Univ. Press.

Barclay, M.J., Smith, C.W., 1995. The maturity structure of corporate debt. Journal of Finance 50, 609-631.

Bardhan, P., 1997. Corruption and development: A review of issues. Journal of Economic Literature 35, 1320-1346.

Booth, L., Aivazian, V., Demirguc-Kunt, A., Maksimovic, V., 2001. Capital structures in developing countries. Journal of Finance 56, 87-130.

Bradley, M., Jarrell, G.A., Kim, H., 1984. On the existence of an optimal capital structure. Journal of Finance 39, 857-878.

Charumilind, C., Kali, R., Wiwattanakantang, Y., 2006. Connected lending: Thailand before the financial crisis. Journal of Business 79 , $181-217$.

Claessens, S., Feijen, E., and Laeven, L., in press. Political connections and preferential access to finance: The role of campaign contributions. Journal of Financial Economics.

Cull, R., Xu, L.C., 2005. Institutions, ownership, and finance: The determinants of profit reinvestment among Chinese firms. Journal of Financial Economics 77, $117-146$.

Demirguc-Kunt, A., Maksimovic, V., 1996. Stock market development and firm financing choices. World Bank Economic Review 10, $341-369$.

Demirguc-Kunt, A., Maksimovic, V., 1998. Law, finance and firm growth. Journal of Finance 53, 2107-2137.

Demirguc-Kunt, A., Maksimovic, V., 1999. Institutions, financial markets, and firm debt maturity. Journal of Financial Economics 54, 295-336.

Demirguc-Kunt, A., and Maksimovic, V., 2001. Firms as financial intermediaries: Evidence from trade credit data. Working paper, World Bank and the University of Maryland.

Dinc, I.S., 2005. Politicians and banks: Political influences on government-owned banks in emerging markets. Journal of Financial Economics 77, 453-479.

Faccio, M., 2006. Politically connected firms. American Economic Review 96, 369-386.

Faccio, M., Masulis, R., McConnell, J.J., 2006. Political connections and corporate bailouts. Journal of Finance 61, $2597-2635$.

Fan, J.P.H., Titman, S., Twite, G., 2005, An international comparison of capital structure and debt maturity choices. Working paper. Chinese University of Hong Kong, University of Texas-Austin, and University of New South Wales.

Fisman, R., 2001. Estimating the value of political connections. American Economic Review 91, 1095-1102.

Giannetti, M., 2003. Do better institutions mitigate agency problems? Evidence from corporate finance choices. Journal of Financial and Quantitative Analysis $38,185-212$.

Johnson, S., Mitton, T., 2003. Cronyism and capital controls: Evidence from Malaysia. Journal of Financial Economics 67, 351-382.

Johnson, S., McMillan, J., Woodruff, C., 2002. Property rights and finance. American Economic Review 92, 1335-1356.

Kaufmann, D., Wei, S.J., 1998. Does "grease money" speed up the wheels of commerce? Working paper, World Bank and Harvard University.

Khawaja, A.L., Mian, A., 2005. Do lenders favor politically connected firms? Rent provision in an emerging financial market. Quarterly Journal of Economics 120, 1371-1411.

La Porta, R., Lopez-de-Silanes, F., Shleifer, A., Vishny, R., 2002. Government ownership of banks. Journal of Finance 57, $265-301$.

La Porta, R., Lopez-de-Silanes, F., Pop-Eleches, C., Shleifer, A., 2004. Judicial checks and balances. Journal of Political Economy 112, $445-470$.

Leuz, C., Oberholzer-Gee, F., 2006. Political relationships, global financing, and corporate transparency. Journal of Financial Economics 81, 411-439.

Li, K., Yue, H., Zhao, L., 2007. Ownership, institutions, and capital structure: Evidence from China. Working paper, University of British Columbia.

Lui, F., 1985. An equilibrium queuing model of bribery. Journal of Political Economy 93, 760-781.

MacKay, P., Phillips, G.M., 2001. Is there an optimal industry capital structure? Working paper, University of Maryland.

Miller, M.H., 1977. Debt and taxes. Journal of Finance 32, 261-275.

Modigliani, F., Miller, M.H., 1958. The cost of capital, corporate finance, and the theory of investment. American Economic Review $48,261-297$. 
Myers, S., Majluf, N., 1984. Corporate financing and investment decisions when firms have information that investors do not have. Journal of Financial Economics 13, 187-221.

Peterson, M., 2005. Estimating standard errors in financial panel data sets: Comparing approaches. Working paper, Northwestern University.

Rajan, R., Zingales, L., 1995. What do we know about capital structure? Some evidence from international data. Journal of Finance 50, $1421-1460$.

Ramalho, R., 2003. The effects of an anti-corruption campaign: Evidence from the 1992 presidential impeachment in Brazil," Working Paper, MIT.

Sapienza, P., 2004. The effects of government ownership on bank lending. Journal of Financial Economics 72, 357-384.

Shleifer, A., Vishny, R., 1994. Politicians and firms. Quarterly Journal of Economics 109, 995-1025.

Shleifer, A., Vishny, R., 1998. The Grabbing Hand: Government Pathologies and their Cures. Harvard Univ. Press, Cambridge, MA.

Siegel, J., 2005. Contingent political capital and international alliances: Evidence from south Korea. Working paper, Harvard Business School.

Smith, C., Warner, J.B., 1979. On financial contracting: An analysis of bond covenants. Journal of Financial Economics 7, 117-161.

Titman, S., Wessels, R., 1988. The determinants of capital structure choice. Journal of Finance 43, 1-19.

Tong, D.C., 2005. Corporate governance and securities regulations in mainland China. Seminar paper. China Securities Regulatory Commission, presented at Chinese University of Hong Kong (May 5). 